Florida International University FIU Digital Commons

$6-17-2010$

\title{
Molecular characterization of GcC8 alpha, the functional homologue of human C8 alpha in the shark, Ginglymostoma cirratum
}

Lydia Tatiana Aybar

Florida International University

DOI: $10.25148 /$ etd.FI14032381

Follow this and additional works at: https://digitalcommons.fiu.edu/etd

Part of the Biology Commons

\section{Recommended Citation}

Aybar, Lydia Tatiana, "Molecular characterization of GcC8 alpha, the functional homologue of human C8 alpha in the shark, Ginglymostoma cirratum" (2010). FIU Electronic Theses and Dissertations. 1350.

https://digitalcommons.fiu.edu/etd/1350 
FLORIDA INTERNATIONAL UNIVERSITY

Miami, Florida

MOLECULAR CHARACTERIZATION OF GcC8 ALPHA, THE FUNCTIONAL HOMOLOGUE OF HUMAN C8 ALPHA IN THE SHARK, GINGLYMOSTOMA CIRRATUM

A thesis submitted in partial fulfillment of the requirements for the degree of

MASTER OF SCIENCE

in

BIOLOGY

by

Lydia Tatiana Aybar 
To: Dean Kenneth Furton

College of Arts and Sciences

This thesis, written by Lydia Tatiana Aybar, and entitled Molecular Characterization of GcC8 alpha, the Functional Homologue of Human C8 alpha in the Shark, Ginglymostoma cirratum, having been approved in respect to style and intellectual content, is referred to you for judgment.

We have read this thesis and recommend that it be approved.

Sylvia L. Smith

Dong-Ho Shin

Date of Defense: June 17, 2010

Charles H! Bigger, Major Professor

The thesis of Lydia Tatiana Aybar is approved.

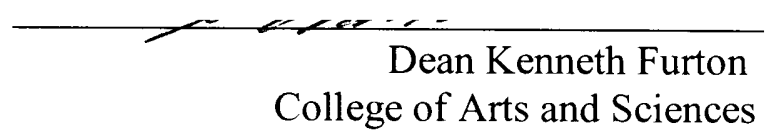

Interim Dean Kevin O'Shea

University Graduate School

Florida International University, 2010 
ABSTRACT OF THE THESIS

MOLECULAR CHARACTERIZATION OF GcC8 ALPHA, THE FUNCTIONAL HOMOLOGUE OF HUMAN C8 ALPHA IN THE SHARK, GINGLYMOSTOMA

CIRRATUM

by

Lydia Tatiana Aybar

Florida International University, 2010

Miami, Florida

Professor Charles H. Bigger, Major Professor

The focus of this study is to elucidate the components of the nurse shark

(Ginglymostoma cirratum) membrane attack complex (MAC), specifically complement component $\mathrm{C} 8 \alpha(\mathrm{GcC} 8 \alpha)$. Nurse shark $\mathrm{C} 8 \alpha$ gene was cloned, sequenced, and analyzed and Western blot analysis performed to identify components of shark MAC. GcC8 $\alpha$ consists of 2341 nucleotides that translate into a 589 amino acid sequence that shares $41.1 \%$ and $47.4 \%$ identity with human and xenopus C8 $\alpha$, respectively. GcC $8 \alpha$ conserves the MAC modular architecture and cysteine-rich backbone characteristic of complement proteins, including the cysteine residue that forms the $C 8 \alpha-\gamma$ bond as well as the indel that is unique to $\mathrm{C} 8 \alpha$. Conservation of MAC protein structure is evident from crossreactivity of antihuman-MAC antibodies with shark serum proteins in Western blots which confirmed the presence of C8 and C9-like proteins in shark serum, however, did not resolve the question of whether $\mathrm{C} 6$ and/or $\mathrm{C} 7$ like proteins are present in shark. 


\section{TABLE OF CONTENTS}

CHAPTER

PAGE

I. INTRODUCTION 1

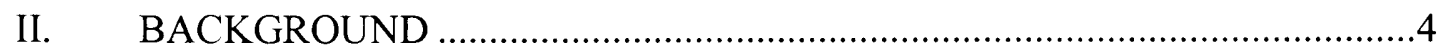

Mammalian Complement..............................................................................

Non-mammalian Complement....................................................................

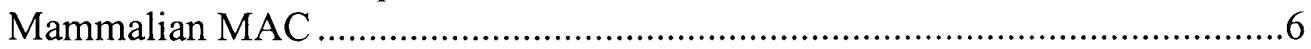

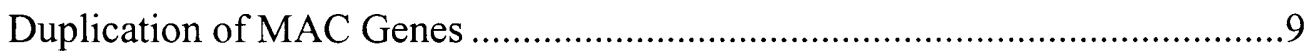

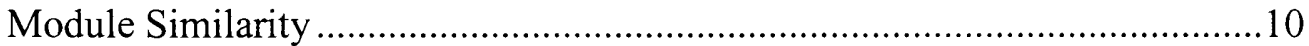

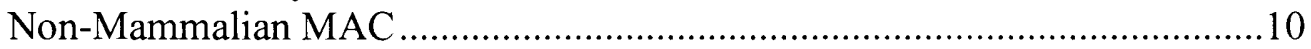

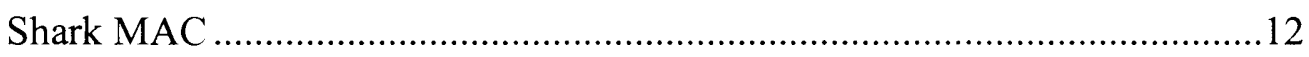

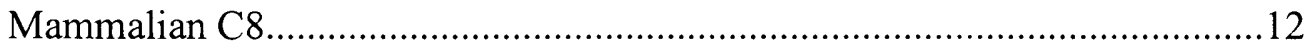

Shark C8

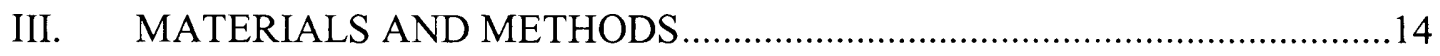

Harvesting of Nurse Shark Tissues...............................................................14

Shark Blood Collection and Processing ..........................................................14

Total RNA Extraction from Shark Tissues .....................................................15

First-strand cDNA Synthesis, Degenerate RT-PCR, and Product Cloning .....16

Conditions for Amplification of GcC8 $\alpha$ DNA sequence .................................17

Preparation of Plasmid DNA and Sequencing...............................................17

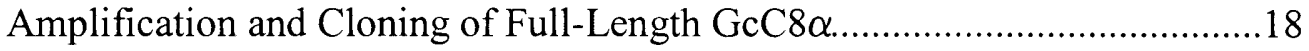

Sequence Compilation and Phylogenetic analysis........................................19

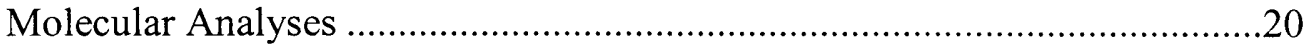

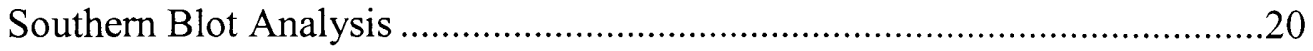

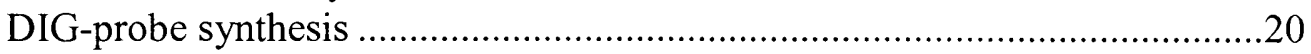

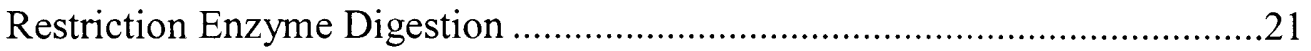

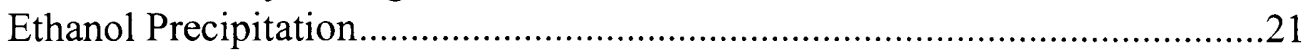

Electrophoresis of Digested Shark Genomic DNA ……...............................22

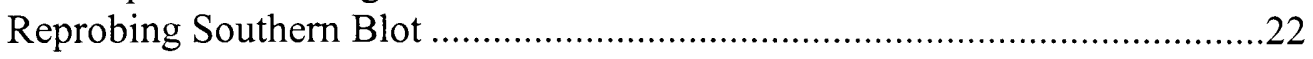

GcC $8 \alpha$ Gene Expression Analysis by RT-PCR ........................................23

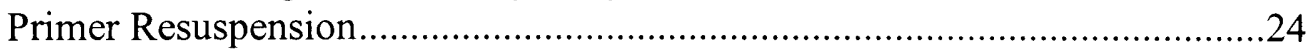

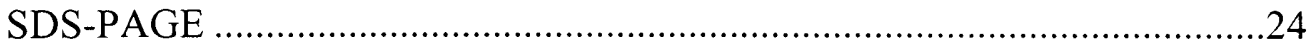

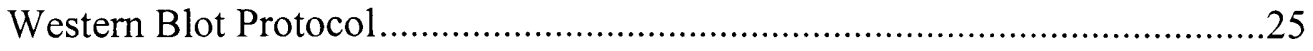

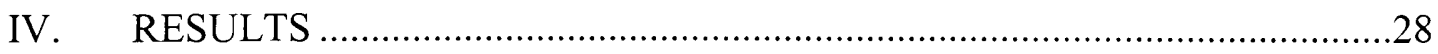

Cloning and Sequence Analysis of the Full-Length GcC $8 \alpha$ cDNA ….............28

GcC $8 \propto$ Percent Identity and Similarity Across Taxa ...................................28

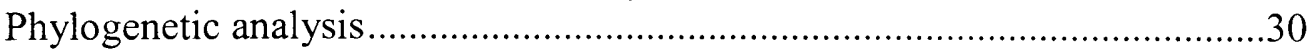

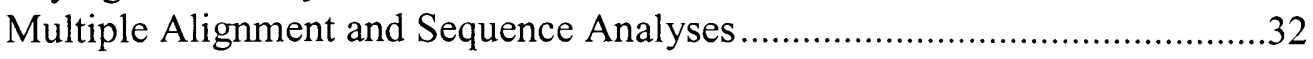




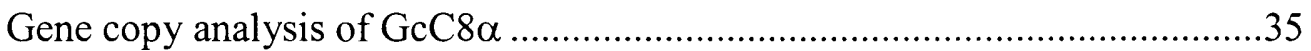

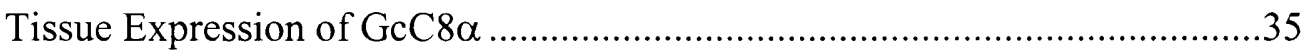

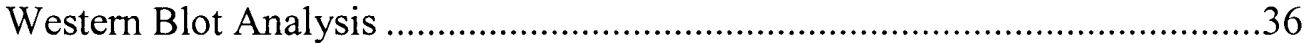

Western blot using Anti-human C9 antisera ...................................................36

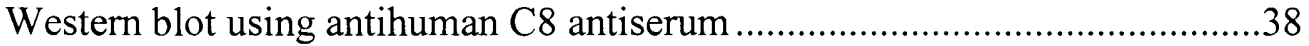

Western blot using antihuman C7 antiserum ...............................................40

Western blot using antihuman C6 antiserum ...............................................4

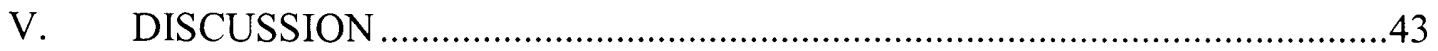

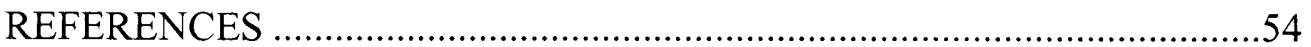




\section{LIST OF TABLES}

TABLE

1. Primers used for sequence analysis, synthesizing PCR- Digoxigenin (DIG) probes, and RT-PCR analysis of the GcC8 $\alpha$ gene.............................................16

2. DIG-Labeled probe PCR reaction mixture .......................................................21

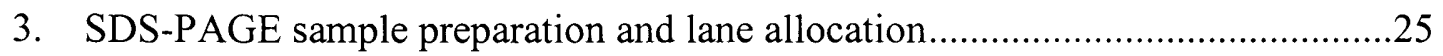

4. Percent Identity and Similarity between the deduced amino acid $\mathrm{GcC} 8 \alpha$ sequence

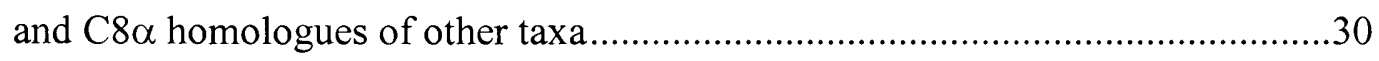

5. Accession numbers correlating with sequences used in Figure 5 phylogeny .........30 


\section{LIST OF FIGURES}

FIGURE

PAGE

1. Modular structure of mammalian MAC protein family. 3

2. Sequential assembly of the membrane attack complex via the terminal lytic pathway of mammalian complement 7

3. Schematic of primer local and overlapping clones of $\mathrm{GcC} 8 \alpha$ gene .18

4. Nucleotide and deduced amino acid sequence of $\mathrm{GcC} 8 \alpha \mathrm{cDNA}$ .29

5. Phylogenetic analysis of MAC amino acid sequences across taxa 31

6. Full-length amino acid sequence alignment in ClustalW of GcC8 $\alpha$ with homologues from other vertebrates: Homo sapiens, Mus muluscus,

Xenopus tropicalis, and Oncorhynchus mykiss.

7. Alignment comparison of shark $\mathrm{C} 8 \alpha$ insertion/deletion sequences (indel) with those of other taxa

8. Modular and Glycosylation site map comparison of Human and Shark C8 $\alpha$ 34

9. Molecular analysis: Hydrophobicity profile of shark $\mathrm{C} 8 \alpha$ (grey) and human C $8 \alpha$ (black) using the Kyte \& Doolittle scale computed in the BioEdit program

10. Southern blot analysis

11. Tissue expression of $\mathrm{GcC} 8 \alpha$ .38

12. Western blot of $\mathrm{C} 9$ using whole shark serum, shark supernatent 1 , and human serum samples under reducing $(\mathrm{R})$ and non-reducing $(\mathrm{NR})$ conditions. ...39

13. Western blot of $\mathrm{C} 8$ using whole shark serum, shark supernatent 1 , and human serum samples under reducing $(\mathrm{R})$ and non-reducing $(\mathrm{NR})$ conditions ...40

14. Western blot of $\mathrm{C} 7$ using whole shark serum, shark supernatent 1 , and human serum samples under reducing $(\mathrm{R})$ and non-reducing $(\mathrm{NR})$ conditions 


\section{CHAPTER I.}

\section{INTRODUCTION}

The focus of this study is to elucidate the components of the shark membrane attack complex (MAC), specifically its $\mathrm{C} 8 \alpha$ ortholog. To further our understanding of the evolution of the complement system, it is essential that components of the cascade be defined, specifically the characterization of the genes that encode the key proteins like those involved in membrane attack. As a first step in this endeavor, the nurse shark $\mathrm{C} 8 \alpha$ gene was cloned, sequenced, and analyzed and Western blot analysis was performed to assess individual constituents of shark MAC, the end product of the terminal pathway of complement.

The complement system is a group of heat labile serum proteins that are generally synthesized by the liver and that circulate as inactive precursors (with the exception of factor D). Complement activation occurs via three distinct activation pathways: the classical (CP), the alternative (AP), or the lectin (LP) (Muller-Eberhard, 1988; Volanakis, 1998; Lambris et al., 1999). All three activation pathways converge into a single terminal lytic pathway leading to the formation of MAC (Podack, 1988). MAC glycoproteins, C5b-C9, assemble sequentially, penetrate target cell membranes, and cause cell death (Podack, 1988). Complement genes, including those that encode the MAC proteins, are believed to have been generated by gene duplication events (Ohno, 1970; Nonaka et al, 1994). This view point is supported by the similar modular architecture of MAC proteins ( $\mathrm{C} 6$ through $\mathrm{C} 9)$ and that they are more similar to one another than they are to genes of proteins composing the activation pathways of the 
complement system (CP, AP, LP), although all complement proteins do share some common structural motifs. The mammalian MAC family of proteins is structurally composed of combinations of several modules or domains such as the thrombospondin type I (T1), low-density lipoprotein receptor class A (LA), epidermal growth factor precursor (EG) modules, and a large MAC-perforin (MACPF) domain (Figure 1) (Gonzalez et al., 1996). These modules are conserved in mammals (Gonzalez et al., 1996); amphibians (unpublished - genbank sequences); and teleosts (Papanastasiou and Zakardis, 2005; 2006a and b). This study provides evidence of a MAC gene in an elasmobranch, the nurse shark Ginglymostoma cirratum, the most basal organism to have a gene that is characteristic of the MAC family. This study further shows that the key MAC structural modules, T1, LA, EG, and MACPF, are present in the shark and suggests functional similarity of shark MAC to that of its mammalian homologue and a degree of similar antigenic structure since antibodies to human $\mathrm{C} 8$ and $\mathrm{C} 9$ cross react with shark $\mathrm{C} 8$ and C9 in Western blots.

The lytic activity of the nurse shark (Ginglymostoma cirratum) complement system involves functional analogues of mammalian C8 and C9 (Jensen et al., 1973; 1981). This report is the first to describe the human $C 8 \alpha$ subunit ortholog in the shark, GcC $8 \alpha$. The GcC $8 \alpha$ gene consists of 2341 nucleotides that translate into a 589 amino acid sequence that shares $41.1 \%$ and $47.4 \%$ identity with human and xenopus C $8 \alpha$, respectively. GcC $8 \alpha$ conserves the MAC modular architecture and cysteine-rich peptide backbone characteristic of complement proteins, including the cysteine residue that forms the $\mathrm{C} 8 \alpha-\gamma$ bond. Southern blot analysis shows that $\mathrm{GcC} 8 \alpha$ exists as a single-copy gene 
expressed in most tissues with the liver being the main site of synthesis. To further prove that $\mathrm{GcC} 8 \alpha$ is a $\mathrm{C} 8 \alpha$ ortholog, phylogenetic analysis places it in a clade with other $\mathrm{C} 8 \alpha$ orthologs and as a sister taxa to Xenopus. The hydrophobicity profile of $\mathrm{GcC} 8 \alpha$ is consistent with the human $\mathrm{C} 8 \alpha$ hydrophobicity pattern with the presence of hydrophobic residues essential for membrane insertion. The conservation of structure and possibly function of MAC proteins is supported by Western blot analysis of shark serum which shows proteins cross-reactive with human anti-MAC antibodies.

This study begins to elucidate shark MAC, specifically its $\mathrm{C} 8 \alpha$ ortholog, to further our understanding of the evolution of an ancient and important part of the innate immune system, the complement system.

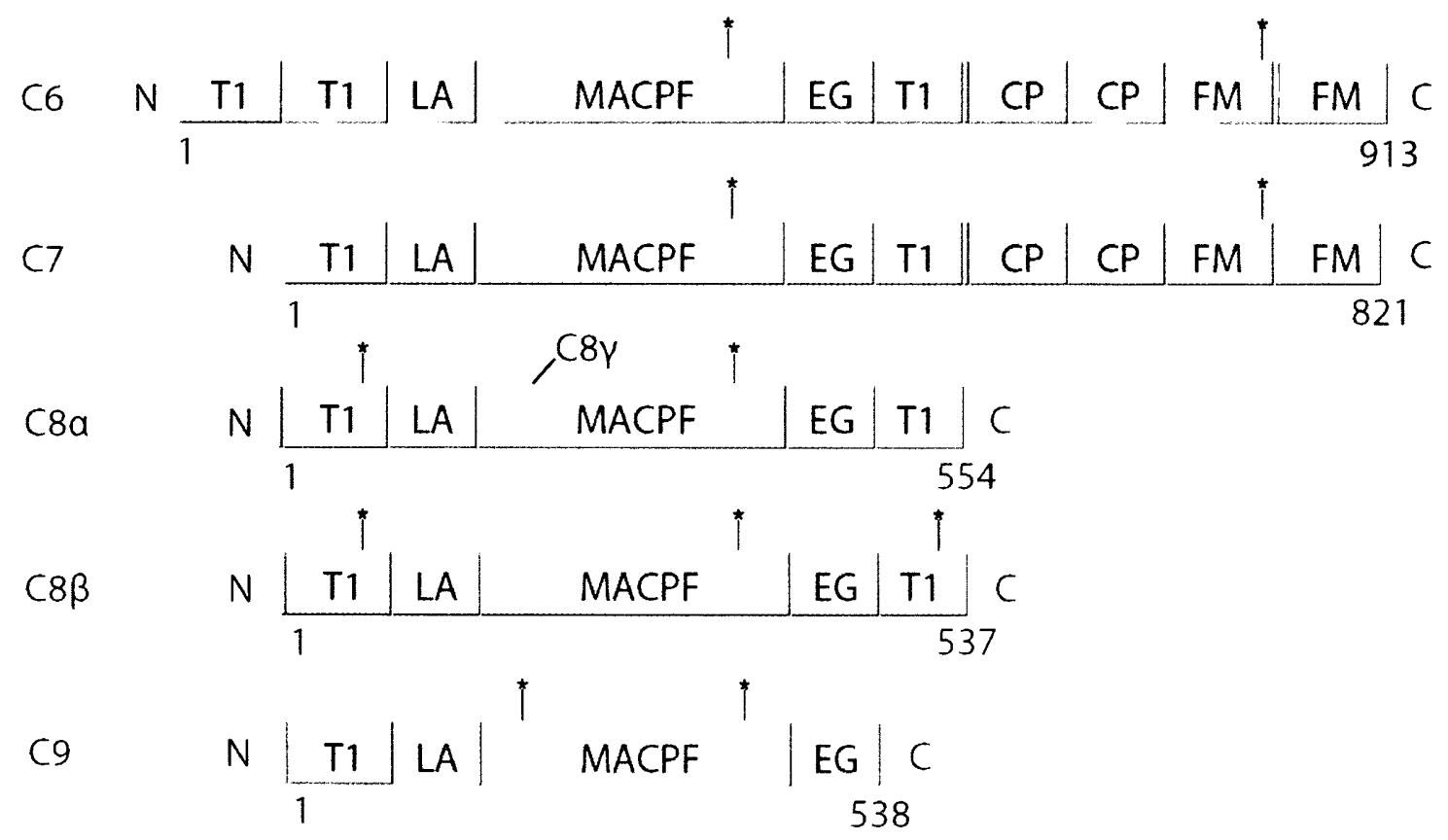

Figure 1. Modular structure of mammalian MAC protein family. Modules are labeled as follows: thrombospondin type I (T1), low-density lipoprotein receptor class A (LA), MAC-perforin (MACPF) domain, epidermal growth factor precursor (EG), Complement control protein (CP), Factor I module (FI). Numbers correspond to protein amino acid residues. Asterisks correspond to potential N-linked glycosylation sites. 


\section{CHAPTER II.}

\section{BACKGROUND}

The nurse shark, Ginglymostoma cirratum, is a primitive member of the vertebrate phyla and, by virtue of its phylogenetic position, serves as an excellent animal model to study ancestral complement genes and proteins, including those of the MAC. The shark immune system has elements of innate and adaptive immunity and, for the purposes of this study, a functional complement system complete with a terminal lytic pathway (Jensen et al., 1973; 1981; Smith, 1998; Smith and Jensen, 1986). Hemolytic activity of shark serum has been known for decades (Legler and Evans, 1967), and transmembrane pore structures formed on target membranes have been shown to be structurally similar to those formed by mammalian MAC (Humphrey and Dourmashkin, 1969; Jensen et al., 1981; Ramm et al, 1982). The shark is the earliest vertebrate for which complement-associated lytic activity has been definitively established and the functional homologues of shark C8 and C9 partially purified (Jensen et al., 1973; 1981); however, the complete molecular composition of shark MAC has not been determined, nor have genes and/or proteins of individual MAC components C6 through C9 been cloned or characterized. The mammalian complement system also includes a complex system of regulatory and control proteins some of which are cell surface-associated proteins (Liszewski et al., 1996).

Mammalian Complement

The complement system is an enzymatic cascade that was named after its ability to 'complement' antibodies in clearing pathogens from an organism (Atkinson and Frank, 1974a and b). Complement has been well-characterized in mammals and consists of three 
activation pathways that converge at $\mathrm{C} 3$ and ends in the formation of $\mathrm{MAC}$ via the terminal, lytic pathway, MAC (Muller-Eberhard, 1988; Götze and Müller-Eberhard, 1971).

Although the complement system is an integral part of innate immunity, it interacts with a component of the adaptive system and thus serves as a bridge between the two systems (Atkinson and Frank, 1974a and b). When complement is activated, a chain of sequential events ensue that leads to the generation of biologically active peptides and assembly of MAC on target membranes (i.e., bacterial cells and transformed self cells). This supramolecular complex penetrates target membranes to form doughnutshaped holes and causes lysis of cells and organisms that leads to cell death (Podack, 1988).

Non-mammalian Complement

Complement has been present in a variety of diverse forms in taxa throughout evolution. Genetic evidence for a C3-homologue has been reported in coral, Swiftia exertia, (Dishaw et al., 2005) and halocynthins (Gross et al., 1999; Marino et al. 2002). One important element of complement conspicuously missing from organisms more basal than elasmobranchs is a terminal lytic pathway. Functional studies in the lamprey (a cyclostome that precedes the shark in evolution) have shown that the opsonic factors of the complement system are present, i.e., C3-Like proteins, but no evidence of assembly of a functional membrane attack complex has been detected (Nonaka et al., 1984), indicating that initiation pathways may be present, but terminated without assembly and execution of membrane attack. In the nurse shark, terminal lysis (Jensen et al. $1973 ; 1981$; Smith and Jensen, 1986) is present along with functional evidence of the 
classical and alternative pathways (Smith, 1998), designating the shark as the most basal organism to have a complete lytic complement system, similar to that found in mammals and other higher vertebrates.

Mammalian MAC

MAC formation is initiated by $\mathrm{C} 5 \mathrm{~b}$ generated by the activation cleavage of $\mathrm{C} 5$ and followed by the sequential assembly of complement proteins $\mathrm{C} 6, \mathrm{C} 7, \mathrm{C} 8$ ( $\alpha, \beta$, and $\gamma$ subunits) and several molecules of C9. The insertion of C5b-C9(n) complex into the target membrane disrupts membrane integrity by forming transmembrane pore-like structures that make cells leaky (Muller-Eberhard, 1988) (Figure 2). The assembly of MAC and its subsequent insertion into the lipid bilayer of target membranes depend on the ability of the terminal components ( $\mathrm{C} 6$ through $\mathrm{C} 9$ ) to undergo conformational changes involving hydrophilic-amphiphilic molecular transition to expose hydrophobic domains to the complementary binding domain of the succeeding MAC protein (Kolb et al, 1972; Kolb and Muller-Eberhart, 1972; Sodetz, 1989; Hadders etal, 2007). A conformational change in $\mathrm{C} 5 \mathrm{~b}$ allows the non-covalent attachment of $\mathrm{C} 6$. Binding of $\mathrm{C} 7$ to the $\mathrm{C} 5 \mathrm{~b} 6$ complex exposes concealed hydrophobic sites within the $\mathrm{C} 7$ molecule, thus permitting insertion of the $\mathrm{C} 5 \mathrm{~b}-\mathrm{C} 7$ complex into the target membrane. Anchored in this way, $\mathrm{C} 5 \mathrm{~b}-7$ serves as a receptor for $\mathrm{C} 8$. The $\mathrm{C} 5 \mathrm{~b}-\mathrm{C} 8$ complex then undergoes a conformational change that exposes a site on $\mathrm{C} 8 \beta$ that begins the polymerization of multiple molecules of $\mathrm{C} 9$ (1-18 in humans) to form a barrel-like tubular structure through the target membrane (Kolb and Muller-Eberhard, 1974; Podack et al, 1978). These channels disrupt target membranes, leading to cell lysis and death from leakage (Podack 
and Tschopp, 1984). The two terminal components, C8 and C9, are crucial for target cell lysis.

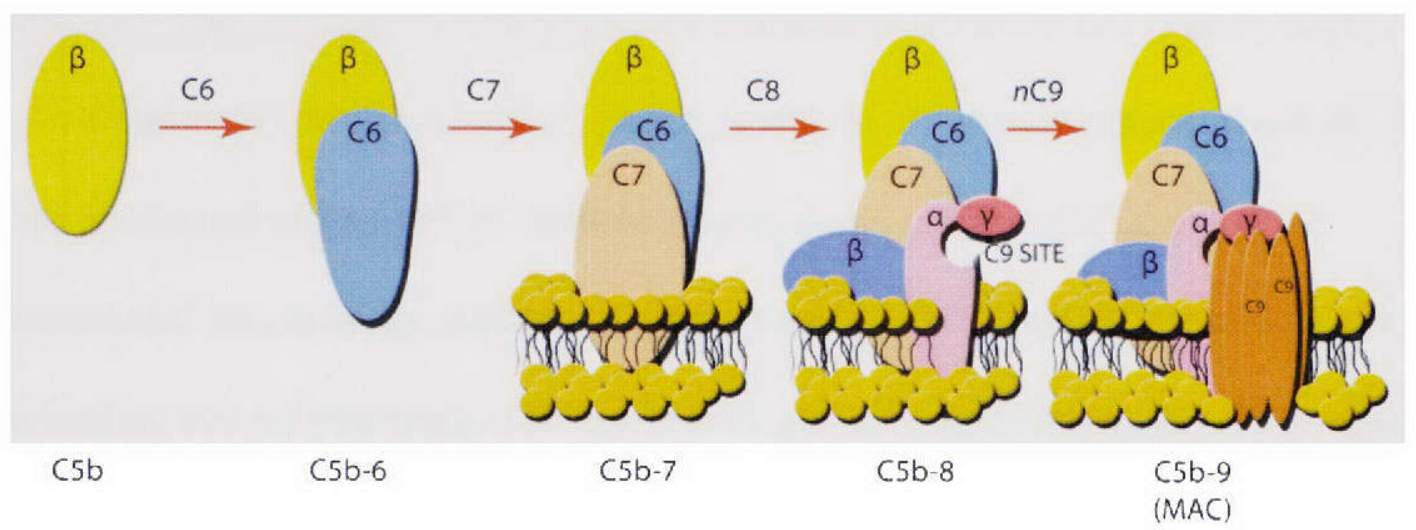

Figure 2. Sequential assembly of the membrane attack complex via the terminal lytic pathway of mammalian complement.

The lytic proteins of cytotoxic lymphocytes, natural killer (NK) cells, and MAC proteins share several common structural motifs, specifically the MACPF domain. The damage caused by MAC is similar to the trans-membrane channels formed by perforin molecules of NK cells on target membranes (Young et al., 1986). Perforin is a protein found in cytolytic T and NK cells that polymerizes to form the same type of doughnutshaped holes as MAC. In the presence of calcium, perforin polymerizes into transmembrane tubules and is capable of lysing, non-specifically, a variety of target cells (Podack et al., 1989). It is generally believed that MAC proteins, C6 through C9 and perforin, arose through a series of gene duplications of an ancestral perforin-like gene 
(Mondragon-Palomino et al., 1999). Thus the MAC complement proteins are considered members of a gene family that includes the perforins.

MAC proteins have high homology to each other, and their interactions are highly specific as is their interaction with target cell membranes (Brannen and Sodetz, 2007). The disulfide bond between $\mathrm{C} 8 \alpha$ and $\gamma$ subunits and the non-covalent binding site of $C 8 \beta$ to $\mathrm{C} 8 \alpha$ are located in the MACPF domain (Plumb et al., 1999). CD59 (protectin) prevents MAC formation by sequestering part of the MACPF domain of $\mathrm{C} 8 \alpha$ to keep $\mathrm{C} 9$ from binding and polymerizing. CD59, a $20 \mathrm{kDa}$ glycophosphatidylinositol-linked glycol protein that acts by binding to $\mathrm{C} 8$ and $\mathrm{C} 9$ to inhibit the formation of the lytic pore, is widely expressed, as it is crucial in preventing destruction of "self" cells by preventing MAC deposition (Kimberley et al., 2007). C9 requires the C8 $\alpha$ LA module as well as the MACPF domain to complete MAC formation (Scibeck et al., 2002).

Two components of MAC differ in genetic structure and belong to non-MAC protein families: $\mathrm{C} 5 \mathrm{~b}$ and $\mathrm{C} 8 \gamma$. $\mathrm{C} 5$ is cleaved by $\mathrm{C} 5$ convertase into $\mathrm{C} 5 \alpha$ and $\mathrm{C} 5 \mathrm{~b}$. $\mathrm{C} 5 \alpha$ is an anaphlytoxin involved in the inflammatory response and causes smooth muscle contraction and vasodilation (Sodetz and Plumb, 2001). C5b is a cleavage product of activated $\mathrm{C} 5$ that is structurally similar and genetically related to the thioester-containing $\alpha_{2}$ Macroglobulin (a2M) protein family, which consists of $\mathrm{C} 3, \mathrm{C} 4, \mathrm{C} 5$, and a2M (Sodetz and Plumb, 2001), and differs from other MAC proteins quite distinctly in that it can noncovalently attach to target membranes to initiate the assembly of MAC, while C $8 \gamma$ is a lipocalin and modulates inflammatory responses (Haefliger et al., 1991). Parker and Sodetz (2002) have shown that MAC can be assembled without C8 $\gamma$ (Brickner and 
Sodetz, 1984). In addition, Trojer et al. (1999) have detected it in the human fetal and adult kidney independent of its $\mathrm{C} 8 \gamma$ counterpart, signifying that these subunits may have roles distinct from complement action. Furthermore, the $\mathrm{C} 8 \gamma$ gene $(\mathrm{C} 8 \mathrm{G})$ is located on a different human chromosome $(9 \mathrm{q})$ than $\mathrm{C} 8 \alpha$ and $\mathrm{C} 8 \beta$, distantly from $\mathrm{C} 8 \mathrm{~A}$ and $\mathrm{C} 8 \mathrm{~B}$ genes (human chromosome $1 \mathrm{p} 32$ ), and because it may not have undergone the gene duplication events it may have evolved separately from other MAC constituents (Platterborze et al, 1996: Rittner et al., 1986).

Duplication of MAC Genes

Biological systems contain many examples of genes that have arisen through the mechanism of gene duplication, which complementologists generally accept as playing an important role in the evolution of the complement system (Nonaka, 2001). Gene duplication in the complement system can be a unique strategy for the immune system to increase the range of recognition of foreign molecules (Sunyer et al., 1998; Nakao et al, 2006). The complement system consists of several examples of related proteins that have arisen by gene duplication, as shown by gene sequence similarity and repetitive modular domain analysis (Figure 1). Several sets of complement components have been discovered in the mammalian complement system that are believed to have arisen from a common ancestor: $\mathrm{C} 1 \mathrm{r} / \mathrm{C} 1 \mathrm{~s}, \mathrm{MASP} 1 / \mathrm{MASP} 2$, factor $\mathrm{B} / \mathrm{C} 2, \mathrm{C} 3 / \mathrm{C} 4 / \mathrm{C} 5$, and $\mathrm{C} 8 \alpha / \mathrm{C} 8 \beta$. These homologous proteins and genes indicate that gene duplication events are common in this system and have given rise to multiple components with similar structures, functions, and domains which are believed to strengthen the functional repertoire of the complement system (Nonaka and Smith, 2000). The overall component structure of complement of teleost and cartilaginous fish is similar to that of mammals; this suggests 
that tetraploidization may have caused the increase in the number of components and emerged after divergence of the cartilaginous fish (Nonaka and Smith, 2000). In-depth sequence and domain analysis indicate that the MAC proteins $\mathrm{C} 6, \mathrm{C} 7, \mathrm{C} 8 \alpha, \mathrm{C} 8 \beta$, and $\mathrm{C} 9$ underwent frequent gene duplication and exon-shuffling that resulted in sequential addition and deletion of the different modular domains (Volankis and Frank, 1998). Module Similarity

Modules are protein scaffolds that have been conserved through biological evolution (Campbell, 2003). One purpose of modules is to provide a binding surface to facilitate interactions among a diverse array of macromolecules, like those of the MAC family, to form dynamic complexes (Campbell, 2003). The MAC proteins C6, C7, C8 $\alpha$, $\mathrm{C} 8 \beta$, and $\mathrm{C} 9$ consist of several cysteine-rich domains or modules such as T1, LA, MACPF, and EG modules (Figure 1) that are commonly found in immune proteins, but that are more structurally and genetically related to each other than to other complement proteins (Sodetz and Plumb, 2001). Some of these modules were first described in systems that were non-complement and non-immune system-related proteins (Morley and Walport, 2000). One essential module present in all MAC proteins (with the exception of $\mathrm{C} 5 \mathrm{~b}$ and $\mathrm{C} 8 \gamma$ ) is the MACPF domain (Figure 1). The presence of common modules is a primary element that suggests that these proteins arose from gene duplication. Non-Mammalian MAC

Information on the composition of MAC for non-mammalian species is incomplete, particularly for lower vertebrates, although genes homologous to mammalian MAC genes and/or proteins have been described for birds (Mikrou and Zarkadis, 2010), frogs (McLin et al., 2008), and teleosts (Nakao et al. 1998; Papanastasiou and Zakardis, 
2005). Little is known of the biological activities associated with these genes and how they compare with those of higher vertebrates (Scapigliati et al., 2001). Molecular tools have revealed complement genes in organisms as ancient as corals (Dishaw et al., 2005) and ascidians (Nonaka et al., 1999), demonstrating that complement-like activity is an ancient immune mechanism. However, a fully functional enzymatic cascade has been described only for the gnathostomes and other vertebrate species, and a functional terminal pathway has not been described in organisms more basal than the shark. Although genes and some components of the classical and alternative activation pathways have been found in agnathans, echinoderms (Smith et al., 1999; Smith et al, 2001) and even cnidarians that evolved prior to the protostome/deuterostome split (Dishaw et al., 2005), no associated target cell lysis has been observed in the afore named organisms and no MAC proteins have been isolated or genes cloned, with the exception of a C6-like gene that has been cloned from amphioxus, a chephalochordate (Suzuki, 2002). Whether the encoded protein functions as a component of a MAC in amphioxus remains to be determined. These genes suggest potential modular structures but are significantly different in composition (Suzuki, 2002).

Individual components analogous to those of the lytic pathway in mammals (i.e., C6 through $\mathrm{C9}$ ) have been described only for few non-mammalian species. C8 $\beta$ has been cloned and characterized in the Japanese flounder, Paralicththys olivaceous (Kalgiri et al., 1999). All three C8 gene subunits have been isolated from carp, Cyprinus carpio (Uemura et al., 1996). $\mathrm{C} 8 \alpha, \beta$, and $\gamma$ genes have been cloned and sequenced in the rainbow trout, Oncorhynchus mykiss (Papanastasiou and Zarkadis, 2005; Kazantzi et al., 2003 ) and in the frog (Xenopus tropicalis) (genbank sequences, unpublished). Studies of 
these genes show that the modular architecture (T1, LA, EG, MACPF) shown in Figure 1 has been conserved in amphibian and teleost MAC counterparts.

Shark MAC

Studies of the complement system in cartilaginous fish have shown functional parallels to mammals that share analogous components (Smith, 1998). Hemolytic activity of shark serum has been recognized for decades, and trans-membrane pore structures formed on target membranes have been shown to be structurally similar to those formed by mammalian MAC (Jensen et al., 1973:1981). The shark complement system has been shown to be structurally and functionally similar to that of humans and other vertebrates (Smith and Jensen, 1986; Shin et al., 2007; Graham et al., 2009; Shin et al., 2009). In the shark, C8 and C9 functional analogues can lyse target cells with human EAC1-C7 or EAC1-C8 cells, respectively (Jensen et al., 1973;1981). Although the shark is the earliest vertebrate for which complement-associated lytic activity has been definitively established, the molecular composition of shark MAC has not been determined nor have genes and/or proteins of individual MAC components C6 through C9 been cloned or characterized. Earlier functional data indicated the presence of C8 and C9 homologues (referred to as $\mathrm{C} 8 \mathrm{n}$ and $\mathrm{C} 9 \mathrm{n}$ or $\mathrm{t} 1$ and $\mathrm{t} 2$ ) in the shark and the proteins were functionally purified from serum.

Mammalian C8

Mammalian C8 is a trimeric oligomer composed of non-identical subunits, $\alpha, \beta$, and $\gamma$ chains, each encoded by a separate gene (C8A, C8B, and C8G) (Steckel et al., 1980; $\mathrm{Ng}$ et al, 1987). As a native composite serum protein, human $\mathrm{C} 8$ has a molecular weight of $151 \mathrm{kDa}$, composed of an $\alpha$ chain $(64 \mathrm{kDa})$, a $\beta$ chain $(64 \mathrm{kDa})$, and a $\gamma$ chain 
(22 kDa) (Kolb and Muller-Eberhard, 1976). Structurally, the $\gamma$ subunit belongs to the lipocalin family and is unrelated to the MAC complement protein family. C8A and $\mathrm{C} 8 \mathrm{~B}$ are located on chromosome 1p32, and C8G is located on 9q (Rittner et al., 1986).

While C5b-7 complex is assembled on the membrane, the binding of $\mathrm{C} 8$ to the complex embeds the complex further into the membrane, causing the target cells to slightly leak. C8 is the first MAC protein to completely insert in the lipid bilayer of the "target" membrane, initiating the anchoring of MAC, which is facilitated through the C8 $\alpha$ subunit (Steckel et al., 1980). C8 $\beta$ in turn is non-covalently bound to the disulfidelinked $\mathrm{C} 8 \alpha$ and $\mathrm{C} 8 \gamma$ subunits. The $\mathrm{C} 8 \alpha$ subunit has a crucial role in completing the assembly of MAC since it rapidly binds and initiates the self-polymerization of C9 molecules which insert into the lipid bilayer and cause osmotic lysis (Musingarimi et al, 2002). C $8 \alpha$ is a subunit that also contains a host of several essential binding sites for the formation and control of MAC function (Plumb et al 1999). It is a unique member of MAC since it is the only MAC protein that hosts a characteristic indel (insertion/deletion sequence) (Plumb and Sodetz, 2000).

Shark $\mathrm{C} 8$

Previous studies on shark have shown the presence of a $185 \mathrm{kDa} C 8$ functional analogue (Jensen et al.1981); however, details of its primary, secondary, and subunit structure were unknown. The goal of the present study was to define shark C8 structure by characterizing the gene(s) of one or more $\mathrm{C} 8$ subunits. This report documents, characterizes, and presents the first nucleotide sequence of a MAC protein in the shark in an evolutionary context using phylogenetic analysis. 


\section{CHAPTER III.}

\section{MATERIALS AND METHODS}

Harvesting of Nurse Shark Tissues

A 2- Kg young female nurse shark was captured from the waters near the Keys Marine Laboratory (KML), Long Key, Florida, and transported in seawater to Florida International University (FIU) for sacrifice and subsequent tissue harvesting. The animal was anesthetized with 1 part per million (ppm) of 3-aminobenzoic acid ethyl ester (methane sulfonate) and allowed to bleed out from the caudal vein. After careful dissection, the tissues were flash-frozen in liquid nitrogen and stored at $-80^{\circ} \mathrm{C}$ until used for nucleic acid extraction.

Shark Blood Collection and Processing

Captive adult nurse sharks were kept in an open seawater channel at the KML. All animals were tagged with an identification number to ensure that animals were not bled more frequently than once every eight weeks. Sharks were anesthetized by handcapturing by net and placing into a concrete bath filled with seawater containing $1 \mathrm{ppm}$ of 3-aminobenzoic acid ethyl ester (methane sulfonate). Anesthetized sharks were removed from the tank and placed in a supine position. Peripheral blood was aseptically drawn from the caudal vein with an 18 -gauge sterile needle directly into a 30 - or 60 -ml syringe. After bleeding, the anesthetized sharks were returned to the water channel and walked to allow the water to flow through the gills until normal respiratory function was restored.

For shark DNA isolation from blood cells, shark blood was added to queen's lysis buffer in a 1:40 ratio and mixed by inversion for $10 \mathrm{~m}$, then placed on ice in a dark cooler. To collect shark serum, shark blood was immediately placed in sterile $50-\mathrm{mL}$ 
polypropylene tubes, wrapped in foil, and placed on ice for transport back to the lab. The tubes were transferred to a $4^{\circ} \mathrm{C}$ refrigerator for $24 \mathrm{~h}$ to clot. Before centrifugation, a sterile wooden applicator stick was used to release the clot from the perimeter of the tube. The tubes were centrifuged in a Beckman GPR centrifuge at $4^{\circ} \mathrm{C}, 12,000 \mathrm{x}$ for $10-15 \mathrm{~m}$. Separated serum was decanted in one fluid movement from the clot into a $50-\mathrm{mL}$ sterile Pyrex glass tube without disturbing the clot. Since some erythrocytes and leukocytes do transfer with the serum, the serum was centrifuged again to remove all erythrocytes and cellular debris at $15,000 \mathrm{x}$ g at $4^{\circ} \mathrm{C}$ for $15-20 \mathrm{~m}$. Clear serum was decanted in to a $50-\mathrm{mL}$ sterile glass Pyrex screw cap tube and stored in a circulating refrigerated water bath (NESLAB) at $0^{\circ} \mathrm{C}$ until further use for functional studies or Western blot analysis. For long term storage, serum was stored frozen at $-20^{\circ} \mathrm{C}$.

Total RNA Extraction from Shark Tissues

Shark tissues (liver, kidney, brain, intestine, ovary, muscle, heart, pancreas, spleen, erythrocytes, and leukocytes) were removed from the $-80^{\circ} \mathrm{C}$ freezer and from each tissue a small sample of approximately $50-100 \mathrm{mg}$ (or $1 \times 10^{7}$ cells) was removed and placed into a $1.5 \mathrm{ml}$ eppendorf tube and homogenized by Kontes Pellet Pestle ${ }^{\circledR}$ motor in 1-ml of TRIzol Reagent (Invitrogen Life Technologies) and left to incubate at room temperature for $5 \mathrm{~m}$. Next, $200 \mathrm{ul}$ of chloroform was added to each tissue sample homogenate, shaken vigorously, and incubated at room temperature for $2 \mathrm{~m}$. Samples were centrifuged at $12,000 \times \mathrm{g}$ for $15 \mathrm{~m}$ at $4^{\circ} \mathrm{C}$. After centrifugation, the RNAcontaining aqueous phase was transferred to a sterile $1.5 \mathrm{ml}$ eppendorf tube. RNA was precipitated by adding $0.5 \mathrm{ml}$ isopropanol and the tube gently inverted and incubated for $10 \mathrm{~m}$ at room temperature. This mixture was centrifuged at $12,000 \times \mathrm{g}$ for $15 \mathrm{~m}$ at $4^{\circ} \mathrm{C}$. 
The supernatant was decanted, and the RNA pellet washed with $1 \mathrm{ml}$ of $75 \%$ ethanol, vortexed, and spun at $7,500 \times \mathrm{g}$ for $5 \mathrm{~m}$ at $4^{\circ} \mathrm{C}$. The ethanol was decanted and the RNA pellet left to air-dry for $10 \mathrm{~m}$. The extracted RNA was dissolved in DEPC treated water and stored at $-80^{\circ} \mathrm{C}$.

First-strand cDNA Synthesis, Degenerate RT-PCR, and Product Cloning

Total RNA was extracted from homogenized nurse shark liver using the TRIzol Reagent (Invitrogen Life Technologies) according to manufacturer instructions (detailed above). Using Superscript II reverse transcriptase and Oligo(dT)12-18 primer (Invitrogen Life Technologies), first-stranded cDNA was synthesized using 4 ug of total RNA as the template. Degenerate primer NSC9-DGF1 (Table 1) was based on a highly conserved region (CNGDQDC, human amino acids 115-121) of human C6, C7, C8 $\alpha$, C8 $\beta$, and C9-deduced amino acid sequences and employed in RT-PCR. NSC9-DGF1 was paired with abridged universal amplification primer (AUAP) (Clontech) for RTPCR.

Table 1: Primers used for sequence analysis, synthesizing PCR- Digoxigenin (DIG) probes, and RT-PCR analysis of the GcC $8 \alpha$ gene.

\begin{tabular}{|l|l|l|}
\hline \multicolumn{1}{|c|}{ Primer Name } & \multicolumn{1}{|c|}{ Sequence 5'-3' } & \multicolumn{1}{c|}{$\begin{array}{c}\text { Location in } \\
\text { sequence }\end{array}$} \\
\hline NSC9-DGF1 & GYAAYGGNGAYAAYGAYTGYG & $115-121$ \\
\hline C8ASAZNF3 & CAAACAGCGAACACGAAGC & $1712-1731$ \\
\hline C8ASAZNRP1 & GAAATCAACAAAGAACACAGAG & $1916-1937$ \\
\hline NSC8A-L2 & GCCGAAAAATCCGAAGTGTA & $143-162$ \\
\hline NSC8A-L3 & GACTGGAGGGAACTGCGATA & $610-629$ \\
\hline C8A33F & AGGCATTGGCACAGTCAG & $1121-1138$ \\
\hline C8AFP10 & TGTCTGCCTGGTTATGAAGG & $1606-1625$ \\
\hline C8A-seqRP1 & CTGGACTTTCTTGCTTCAC & $218-236$ \\
\hline C8A-SQRP1 & TGGTTTTCGGTAGCATTTCTC & $667-687$ \\
\hline C8A-SQRP2 & TTACCGAGCCACCCACA & $1212-1228$ \\
\hline C8A-SQRP3 & GGCACGCTTTCCCTTCAT & $1619-1636$ \\
\hline
\end{tabular}




\begin{tabular}{|l|l|l|}
\hline C8a-ESFP2 & ATTACACTGCATGAAGAATGA & $11-31$ \\
\hline C8a-ESRP1 & CTGGTAATGATGGACCTGG & $2075-2093$ \\
\hline beta-actin F & CTGCCATGTATGTTGCCATC & $389-408$ \\
\hline beta-actin R & ATCCACATCTGCTGGAAGGT & $1051-1070$ \\
\hline M13F & TGTAAAACGACGGCCAGT & \\
\hline M13R & GTTTTCCCAGTCACGAC & \\
\hline
\end{tabular}

${ }^{\mathrm{a}}$ Indicates the amino acid position in human $\mathrm{C} 8 \alpha$ chain

Conditions for Amplification of $\mathrm{GcC} 8 \alpha$ DNA sequence

The thermocycler was set for $94^{\circ} \mathrm{C}$ for $1 \mathrm{~m}$ and 35 cycles of $94^{\circ} \mathrm{C}$ for $30 \mathrm{~s}, 56^{\circ} \mathrm{C}$ for $30 \mathrm{~s}$, and $71^{\circ} \mathrm{C}$ for $3 \mathrm{~m}$ and for a final extension for $6 \mathrm{~m}$. DNA fragments of 2.1 and $2.9 \mathrm{~Kb}$ were detected by electrophoresis and further amplified by nested PCR (SMARTRACE cDNA amplification kit, Invitrogen Life Technologies) under thermocycler settings of $94^{\circ} \mathrm{C}$ for $30 \mathrm{~s}, 62^{\circ} \mathrm{C}$ for $30 \mathrm{~s}, 72^{\circ} \mathrm{C}$ for $3 \mathrm{~m}$, and $30 \mathrm{~s}$ for 25 cycles. The PCR products were run on a $1 \%$ agarose gel and further purified using the QIAquick gel extraction kit (Qiagen) according to manufacturer's instructions. The extracted products were cloned into a TOPO-TA 10F' vector (lnvitrogen Life Technologies). Recombinants were identified by blue/white colony selection on ampicillin-containing LB agar plates.

Preparation of Plasmid DNA and Sequencing

Clones positive for the expected $2.1 \mathrm{~Kb}$ insert (based on primer design) were selected by colony PCR. Colony PCR amplification was carried out for 30 cycles of $94^{\circ} \mathrm{C}$ for $30 \mathrm{~s}, 51^{\circ} \mathrm{C}$ for $30 \mathrm{~s}$, and $72^{\circ} \mathrm{C}$ for $2 \mathrm{~m}$. Plasmids of selected clones were purified using the SV Minipreps DNA purification system (Promega). The purified plasmids were subjected to cycle sequencing reactions composed of $2 \mu 1$ Big Dye Terminator V3.1 (Applied Biosystems); $4 \mu \mathrm{l}$ purified plasmid DNA (35 ng $\mu \mathrm{l}$ ); $2 \mu$ l Bigdye terminator 
buffer; and $2 \mu 1(0.8 \mu \mathrm{M})$ gene-specific primer. All cycle sequencing reactions were carried out as follows: initial denaturation at $96^{\circ} \mathrm{C}$ for $1 \mathrm{~m}$, followed by 30 cycles of $96^{\circ} \mathrm{C}$ for $5 \mathrm{~s}, 50^{\circ} \mathrm{C}$ for $10 \mathrm{~s}$, and $60^{\circ} \mathrm{C}$ for $4 \mathrm{~m}$ (Sanger et al., 1977). The resulting cycle sequencing products were submitted for sequencing by the ABI377 (Applied Biosystems) automated sequencer at the FIU DNA Sequencing Core facility. Clones were subjected to cycle sequencing using M13 forward and reverse primers (Table 1); gene specific primers were constructed from resulting sequences to further sequence the entire gene. All sequencing primers were designed to overlap at the 3 ' end of each reading frame by at least 100 base pairs (Figure 3). Gene specific primers used to identify and sequence $\mathrm{GcC} 8 \alpha$ gene are listed in Table 1.

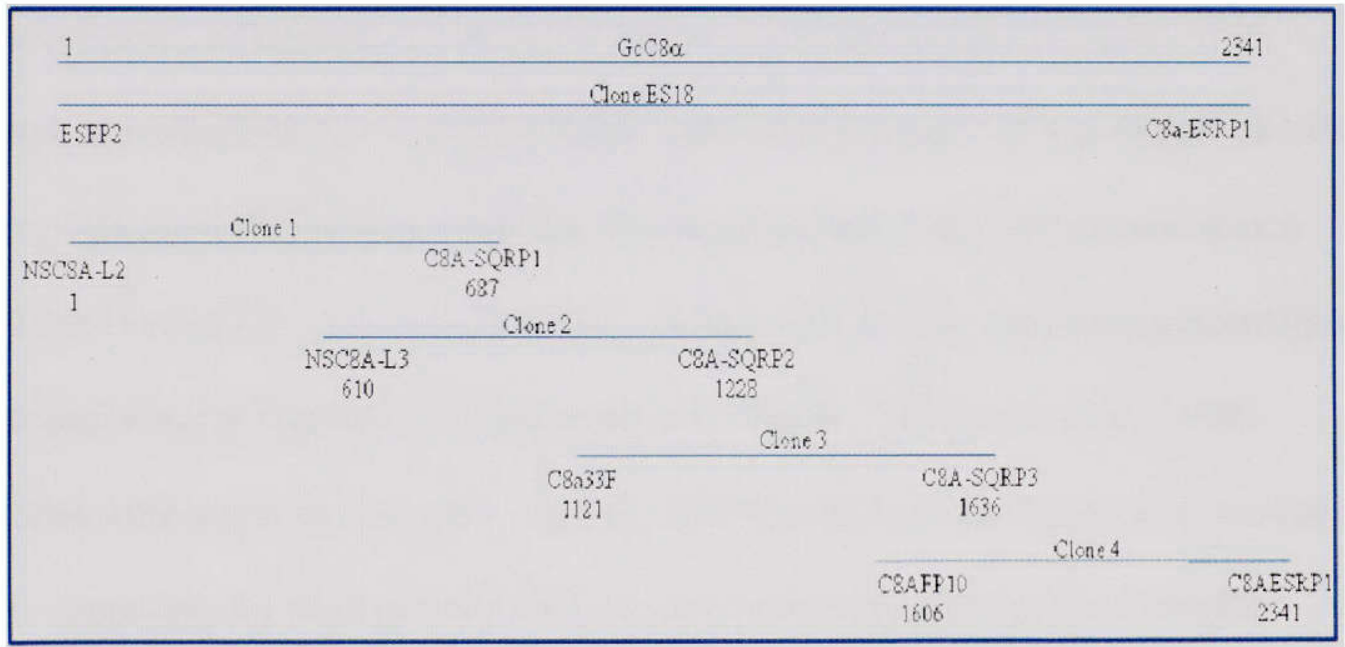

Figure 3: Schematic of primer local and overlapping clones of GcC $8 \alpha$ gene. Amplification and Cloning of Full-Length GcC $8 \alpha$

A full-length $\mathrm{GcC} 8 \alpha$ transcript was obtained by long-PCR using primers C8aESFP2 and C8a-ESRP1 that were designed to the 5' and 3' UTR of the assembled 
sequence generated from overlapping clones (Figure 3). Amplification was carried out for 38 cycles: $94^{\circ} \mathrm{C}$ for $30 \mathrm{~s}, 60^{\circ} \mathrm{C}$ for $30 \mathrm{~s}$, and $70^{\circ} \mathrm{C}$ for $3 \mathrm{~m}$. The PCR mixture was composed of $1 \mu \mathrm{l}$ of each primer $(10 \mu \mathrm{M}), 45 \mu 1$ PCR Supermix High Fidelity (Invitrogen Life Technologies), and $3 \mu 1$ cDNA. The PCR product was run on a $1 \%$ agarose gel with ethidium bromide. The band of expected size was cut out, gel-purified, cloned, and sequenced as described in the cloning procedure employed for the preparation of plasmid DNA and outlined above. Clones positive for the $2.5 \mathrm{~kb}$ insert were selected by colony PCR.

Sequence Compilation and Phylogenetic analysis

The full-length GcC8 $\alpha$ nucleotide sequence was assembled from over-lapping clones (Figure 3) and translated to the corresponding amino acid sequence in the BioEdit biological sequence alignment editor for Windows 95/98/NT/2000/XP (Hall, 1999). Using gene specific primers a complete full-length $\mathrm{GcC} 8 \alpha$ transcript was identified. The identities of positive clones were established using the Basic Local Alignment Search Tool (BLAST) search engine (Altschul et al., 1990). Identity and similarity percentages were calculated using alignments constructed in ClustalW (Thompson et al., 1994). Calculations were made by manually counting identical and similar amino acid residues. Multiple alignments for phylogenetic analysis were constructed using the ClustalX program (Thompson et al., 1997). This alignment was then used in the PAUP* program (Phylogenetic Analysis Using Parsimony, Swafford DL, 2002) to construct a phylogeny using the neighbor joining algorithm (Saitou and Nei, 1987) under the default settings. Confidence in the branch points was validated by 1000 bootstrap replications. Sequences for other species were obtained from GenBank. 
Molecular Analyses

Molecular modules were determined by studying and comparing alignments created by ClustalW of GcC $8 \alpha$ sequence and $\mathrm{C} 8 \alpha$ sequences of other taxa. Potential Nlinked glycosylation sites were predicted by the presence of the amino acid sequon N-X[S or T] (Marshall, 1974), where $\mathrm{X}$ is any amino acid, followed by a Serine (S) or Threonine (T) residue (Figure 4). Potential C-mannosylation sites were identified by searching for the sequon $\mathrm{W}-\mathrm{X}-\mathrm{X}-\mathrm{W}-\mathrm{X}-\mathrm{X}-\mathrm{W}$, where $\mathrm{X}$ is any amino acid (Hofsteenge et al., 1999). Hydrophobicity profiles were generated under the default settings of the Kyte \& Doolittle (1982) algorithm in the BioEdit program (Hall, 1999). Southern Blot Analysis

Southern blot analysis was employed to determine $\mathrm{GcC} 8 \alpha$ gene copy number. Southern blots were developed using a nylon membrane $\left(\right.$ Hybond $\mathrm{N}^{+}$, currently GE Healthcare) that had previously been probed by a DIG labeled probe for another shark complement gene. The following describes how the membrane for the first probe was constructed, how this initial DIG-probe was removed, and the membrane was further hybridized with a probe designed specifically for $\mathrm{GcC} 8 \alpha$.

DIG-probe synthesis

DIG-labeled probe was synthesized using the PCR DIG Probe Synthesis Kit (Roche) to detect copies of the $\mathrm{GcC} 8 \alpha$ gene in restriction enzyme digests of shark genomic DNA using the enzymes BamHI, EcoRI, HindIII, and PstI. Using the pattern of human $\mathrm{C} 8 \alpha$ intron/exon as a template, the primer set C8ASAZNFP3 and C8ASAZNRP1 was designed to cover a 226 nucleotide sequence that did not extend across C8 $\alpha$ introns 
(Morley and Walport, 2000). A plasmid (4 $\mathrm{ng} / \mu \mathrm{l}$ ) containing the full-length $\mathrm{GcC} 8 \alpha$ sequence was used as the template for PCR reaction. Amplification consisted of 35 cycles of $95^{\circ} \mathrm{C}$ for $30 \mathrm{~s}, 54^{\circ} \mathrm{C}$ for $30 \mathrm{~s}$, and $70^{\circ} \mathrm{C}$ for $30 \mathrm{~s}$.

Table 2: DIG-Labeled probe PCR reaction mixture. All buffers, stock, and enzymes provided by PCR DIG Probe Synthesis Kit (Roche).

\begin{tabular}{|l|l|l|}
\hline \multicolumn{1}{|c|}{ Reagent } & \multicolumn{1}{|c|}{ DIG-Probe } & Unlabelled Control \\
\hline Autoclaved water & $16.625 \mathrm{ul}$ & $16.625 \mathrm{ul}$ \\
\hline PCR Buffer & $2.5 \mathrm{ul}$ & $2.5 \mathrm{ul}$ \\
\hline PCR DIG label mix & $2.5 \mathrm{ul}$ & None \\
\hline dNTP stock & None & $2.5 \mathrm{ul}$ \\
\hline Forward Primer & $1 \mathrm{ul} 10 \mathrm{uM}$ & $1 \mathrm{ul} 10 \mathrm{uM}$ \\
\hline Reverse Primer & $1 \mathrm{ul} 10 \mathrm{uM}$ & $1 \mathrm{ul} 10 \mathrm{uM}$ \\
\hline Enzyme Mix & $0.0375 \mathrm{ul}$ & $0.0375 \mathrm{ul}$ \\
\hline Template DNA & $1 \mathrm{ul} \mathrm{of} 4 \mathrm{ng} / \mathrm{ul}$ & $1 \mathrm{ul} \mathrm{of} 4 \mathrm{ng} / \mathrm{ul}$ \\
\hline Total & $25 \mathrm{ul}$ & $25 \mathrm{u}$ \\
\hline
\end{tabular}

Restriction Enzyme Digestion

Shark genomic DNA $(711 \mathrm{ng} / \mu \mathrm{l})$ was digested with restriction enzymes BamHI, EcoRI, HindIII and $P s t \mathrm{I}$ at $37^{\circ} \mathrm{C}$ for $21 \mathrm{~h}$. The restriction enzyme digestion mixture consisted of $300 \mu 1$ of $0.2 \mathrm{X}$ TE Buffer (Invitrogen Life Technologies); $37.5 \mu 1 \mathrm{RE} \mathrm{Buffer}$ 3 (Invitrogen Life Technologies); $30 \mu \mathrm{l}(711 \mathrm{ng} / \mu \mathrm{l})$ shark genomic DNA; and $8 \mu \mathrm{l}$ (10 units/ $\mu$ l) restriction enzyme (Invitrogen Life Technologies).

Ethanol Precipitation

Post-digestion, the nucleic acid was subjected to ethanol precipitation by adding 625 ul of $100 \%$ ethanol to each tube. The tubes were vortexed and incubated at room temperature for $10 \mathrm{~m}$. The digested DNA was further centrifuged at $3250 \mathrm{x}$ g at $4^{\circ} \mathrm{C}$ for $20 \mathrm{~m}$. The supernatant was then discarded and $1.2 \mathrm{ml}$ of $70 \%$ ethanol added and vortexed. 
This mixture was centrifuged at $3250 \mathrm{x}$ g for $5 \mathrm{~m}$ at $4^{\circ} \mathrm{C}$ and the supernatant discarded. The tubes were then inverted on clean tissue paper for 20-27 $\mathrm{m}$ to air-dry the DNA. Finally, the precipitated DNA was re-suspended in $80 \mu \mathrm{l}$ of $0.2 \mathrm{X}$ TE buffer and stored at $4^{\circ} \mathrm{C}$ until Southern Blot analysis was performed. Electrophoresis of Digested Shark Genomic DNA

The digested shark genomic DNA ( $5 \mu \mathrm{g} /$ lane) was electrophoresed in $0.8 \%$ agarose gel at $22 \mathrm{~V}$ for $10 \mathrm{~h}$. The gel was then stained in $300 \mathrm{ml}(0.5 \mu \mathrm{g} / \mathrm{ml})$ of ethidium bromide in $1 \mathrm{X}$ TAE buffer. The digested DNA was further cut by immersing and agitating the stained gel in $500 \mathrm{ml}$ of $0.25 \mathrm{~N} \mathrm{HCl}$ at room temperature for $20 \mathrm{~m}$. The DNA on the gel was denatured to keep the DNA fragments single stranded in $0.2 \mathrm{M}$ $\mathrm{NaOH} / 0.6 \mathrm{M} \mathrm{NaCl}$ for $15 \mathrm{~m}$ at room temperature twice. The gel was then rinsed with deionized water. The DNA from the gel was transferred onto a Hybond $\mathrm{N}+$ nitrocellulose membrane by capillary action blotting for $17 \mathrm{~h}$ at room temperature. The DNA was immobilized under the "optimal" (120 mJ) setting option of the UV cross-linker. Reprobing Southern Blot

As stated earlier, a previously probed membrane was used after stripping the membrane. To remove existing probe the used membrane was rehydrated in $\mathrm{ddH}_{2} \mathrm{O}$ for 2-3 $\mathrm{m}$, then submerged in $0.2 \mathrm{~N} \mathrm{NaOH} / 0.1 \%$ SDS probe removal solution under agitation at $37^{\circ} \mathrm{C}$ for $10 \mathrm{~m}$. The membrane was removed from the solution, washed a second time with the probe removal solution, and incubated a second time. The membrane was then equilibrated by agitation in $2 \mathrm{XSSC}$ at room temperature for $2-3 \mathrm{~m}$. The membrane was placed in a hybridization tube with $5 \mathrm{ml}$ of $42^{\circ} \mathrm{C}$ prehybridization solution $(5 \mathrm{XSSC}, 2 \%$ milk, $7 \% \mathrm{SDS}, 0.05 \mathrm{mg} / \mathrm{ml}$ salmon sperm DNA in $\mathrm{ddH}_{2} \mathrm{O}$ ) and incubated in a 
hybridization chamber at $42^{\circ} \mathrm{C}$ for $2-4 \mathrm{~h}$. After prehybridization, hybridization solution ( $5 \mathrm{ml}$ prehybridization solution and $10 \mu \mathrm{l}$ DIG-labeled probe) was added to blot in the hybridization tube and incubated overnight $(16-18 \mathrm{~h})$ at $42^{\circ} \mathrm{C}$. The membrane was removed from the hybridization tube, placed in a wash solution (2X SSC, $0.1 \%$ SDS in $\mathrm{ddH}_{2} \mathrm{O}$ ), and agitated for $15 \mathrm{~m}$ at $42^{\circ} \mathrm{C}$. This wash step was repeated two times. Then, stringent washing was performed twice in $0.1 \mathrm{xSSC}$ and $0.1 \%$ SDS for $30 \mathrm{~m}$ at $42^{\circ} \mathrm{C}$. Then, DIG buffer 3 was added to the membrane and agitated for $5 \mathrm{~m}$ at room temperature. The membrane was heat-sealed in a plastic bag with $1 \mathrm{ml}$ LUMI-PHOS Plus solution (Lumigen), wrapped in foil, and incubated for $45 \mathrm{~m}$ at $37^{\circ} \mathrm{C}$. Finally, under red light, $\mathrm{x}$-ray film was placed along with the membrane in a film cassette for $3 \mathrm{~h}$. After incubation, the film was removed and placed in developer solution (Kodak) until band formation was visualized. The $\mathrm{x}$-ray film was dipped in stop solution $(20 \%$ acetic acid in $\mathrm{ddH}_{2} \mathrm{O}$ ) for $2 \mathrm{~m}$, and finally into fixer solution (Kodak) for $3 \mathrm{~m}$. The film was washed by running water and then hung to air dry.

GcC $8 \alpha$ Gene Expression Analysis by RT-PCR

As described, the first-strand cDNA that was synthesized from each tissue was used as a template for RT-PCR. Employing the primers NSC8A-L2 (forward) and C8ASQRP1 (reverse) (Table 1) that span a 503 nucleotide region of the $\mathrm{GcC} 8 \alpha$ sequence, RT-PCR was performed under thermocycler settings of 42 cycles of $94^{\circ} \mathrm{C}$ for $30 \mathrm{~s}, 54^{\circ} \mathrm{C}$ for $30 \mathrm{~s}$, and $72^{\circ} \mathrm{C}$ for $50 \mathrm{~s}$. Universal $\beta$-actin specific primers for $\beta$-actin (forward: $5^{\prime}$ CTGCCATGTATGTTGCCATC -3' (nucleotide numbers, 389-408) and reverse 5'ATCCACATCTGCTGGAAGGT-3' (nucleotide numbers 1051-1070) were run simultaneously as a control at the same thermocycler settings except that amplification 
was carried out for 32 cycles. PCR products were electrophoretically analyzed on a $1 \%$ agarose gel containing ethidium bromide.

Primer Resuspension

All primers were purchased desalted from Sigma- Genosys (currently SigmaAldrich) and reconstituted to $100 \mu \mathrm{M}$ stock solutions in autoclaved sterile $\mathrm{ddH}_{2} \mathrm{O}$. All primers were stored at $-20^{\circ} \mathrm{C}$ after resuspension.

SDS-PAGE

Preparation of Supernatant 1 from shark serum

Low ionic strength precipitation of shark serum was achieved by adding cold water to reduce ionic strength of serum to $4 \mathrm{mS}$ as measured by a conductivity probe. The diluted serum was then kept on ice and swirled intermittently for $1 \mathrm{~h}$. The diluted serum was centrifuged at $1000 \mathrm{x}$ g for $40 \mathrm{~m}$ to separate and remove the precipitated proteins (Precipitate 1) from the supernatant (Supernatant 1), which was stored at $4^{\circ} \mathrm{C}$ until used in SDS-PAGE and Western blot procedures. Lowering the ionic strength of shark serum by dilution results in precipitation of the bulk of proteins such as $\mathrm{Clq}$ and shark immunoglobulin which can interfere with reactions in Western blots.

Sample Preparation

Samples of human serum, shark serum, and shark Supernatant 1 sample were prepared for SDS-PAGE electrophoresis according to Table 3. Physiological saline was used when samples were diluted as described in Table 3. Gels designated for Western blot analysis were loaded with pre-stained molecular weight standards while gels that were to be stained with Coomasie blue were loaded with unstained protein standards. All samples and reference standards were heated to $95^{\circ} \mathrm{C}$ in a water bath for $5 \mathrm{~m}$ and 
centrifuged at $8000 \mathrm{x}$ g before loading; $25 \mu$ l of each sample was loaded onto a separate lane in the gel.

Table 3: SDS-PAGE sample preparation and lane allocation

\begin{tabular}{|l|c|c|c|c|c|r|r|}
\hline \multicolumn{1}{|c|}{ Lanes } & 1 & 2 & 3 & 4 & 5 & 6 & 7 \\
\hline Sample & SS & SS-R & Spt1 & Spt1-R & HS & HS-R & BRPS \\
\hline Dilution & $1: 50$ & $1: 50$ & None & None & $1: 50$ & $1: 50$ & \\
\hline Sample & & & & & & & \\
\hline ul Serum/Spt1 & 1 & 1 & 20 & 20 & 0.66 & 0.66 & \\
\hline ul Physiological Saline & 19 & 19 & None & None & 19.34 & 19.34 & \\
\hline ul R buffer & & 5 & & 5 & & 5 & \\
\hline ul NR Buffer & 5 & & 5 & & 5 & & \\
\hline
\end{tabular}

NR: non-reduced, R: reduced, SS: shark serum, Spt1: Supernatant 1, HS: human serum, BRPS: Broad Range Protein Standards

Using Bio-Rad Criterion electrophoresis cell with Bio-Rad Model 200/2.0 power supply, gels were run in $1 \mathrm{X}$ tris-glycine running buffer at $200 \mathrm{~V}$ until the dye front had migrated to the end of the gel. When the dye front reached the bottom of the gel, electrophoresis was halted and the gel assembly dismantled. The left side of the gels was nicked to show the direction in which the gel was loaded, the gels were then immersed in Fermentas PageBlue staining solution for $5 \mathrm{~m}$ and rinsed in water until most of the dye was removed. After destaining ( $20 \%$ methanol, $10 \%$ acetic acid), the gels were photographed, then wrapped in one layer of cellophane and vacuum-dried on a Model 543 gel dryer (Bio-Rad).

Western Blot Protocol

Four pairs of SDS-PAGE gels were run as described above. One gel of each pair was used to stain as described to visualize all protein bands of each sample, while the 
other was used to blot. The blotting gels were rinsed in water and assembled into the blotting sandwich. The sandwich was assembled as follows: the cassette was laid black side down. A fiber pad was placed on the black side, then filter paper, the gel, the nitrocellulose membrane, more filter paper, and last, a fiber pad. The cassette was closed and placed in the transfer chamber. Prior to assembly, all sandwich materials (nitrocellulose membrane, filter pads, and filter paper) were equilibrated in Nupage transfer buffer (Invitrogen Life Technologies). An ice block was added to the chamber along with a stir bar to prevent damage to the blot from the heat generated by the electrical current. The chamber was filled with transfer buffer, placed on a stir plate, and connected to the power supply. The apparatus was subjected to $100 \mathrm{~V}$ for $1 \mathrm{~h}$. To confirm complete protein transfer from gel to membrane, the sandwich was disassembled and the gels were stained with Coomasie blue which would stain proteins that did not transfer and remained in the gel. All washing and incubations were subjected to agitation to ensure adequate homogenous covering of the membrane and prevent uneven binding. The membranes were immersed in blocking solution of $5 \%$ milk (Carnation) for $1.5 \mathrm{~h}$ in a dark container. The solution was replaced with fresh blocking solution and the blots were left at $10^{\circ} \mathrm{C}$ overnight. The blocking solution was removed and wash diluent buffer (WDB: $200 \mathrm{ml} 1 \mathrm{XTBS}, 2 \mathrm{~g}$ instant milk, $100 \mu \mathrm{l}$ Tween 20) was added to the membrane and agitated for $10 \mathrm{~m}$. This step was repeated three times. Then, $10 \mathrm{ml}$ of primary antibody solution (1XTBS, 1\% milk, and 1:200 diluted goat anti-human C6, C7, C8, or C9 antibodies purchased from Quaigen) was added and agitated for $3 \mathrm{~h}$. The blot was then washed with WDB for $20 \mathrm{~m}$ twice at room temperature, then $10 \mathrm{ml}$ of secondary antibody solution (1XTBS, 1\% milk, and peroxidase-tagged rabbit anti-goat 
immunoglobulin (Ig) secondary antibody (1:500)) was added to the blot and incubated for $1 \mathrm{~h}$ with agitation. The secondary antibody solution was decanted and the blot was washed twice with WDB for $10 \mathrm{~m}$ each time. The protein blot was then developed by the addition of BioRAD HRP (horse radish peroxidase) Conjugate Substrate kit until reactive bands appeared. Precaution was taken not to allow development to proceed for too long in order to avoid and minimize non-specific reactions. 


\section{CHAPTER IV.}

\section{RESULTS}

Cloning and Sequence Analysis of the Full-Length GcC $8 \alpha$ cDNA

A 2341 nucleotide sequence was constructed from overlapping clones (Figure 3 and 4) that included the 3' and 5' UTRs. Table 1 lists the primers used. From these overlapping clones a single cDNA sequence was determined (Figure 3 and 4). Gene specific primers designed C8a-ESFP2 and C8a-ESRP1, were designed based on the compiled sequence and used in PCR amplification (Frohman et al., 1988) to generate a mRNA transcript representing the full-length shark $\mathrm{C} 8 \alpha$ gene. Several clones representing a single fulllength cDNA sequence with the 3' and 5' UTRs and high homology to C8 $\alpha$ of the human, mouse, rat, rabbit, and pig were identified. The nucleotides (1770) of the coding region were translated using the BioEdit program (Figure 4) into 589 amino acid residues.

GcC $8 \alpha$ Percent Identity and Similarity Across Taxa

Using the computer software ClustalW, the deduced $\mathrm{GcC} 8 \alpha$ amino acid sequence was aligned with other known $\mathrm{C} 8 \alpha$ amino acid sequences of the human, mouse, rat, pig, and rabbit (Figure 6). The percentage of amino acid identity and similarity between GcC $8 \alpha$ and $\mathrm{C} 8 \alpha$ sequences from other species was calculated (Table 4). The average amino acid sequence identity between the nurse shark $\mathrm{C} 8 \alpha$ gene and human, mouse, rat, pig, and rabbit known C8 $\alpha$ sequences ranged from $38.7-47.4 \%$ identity and $65.4-$ $78.4 \%$ similarity. 
91 AATTCGAATCAGATCAGCAACAGTTCAAAACATTGTTGCACGCATCAGTCTGGCCGAAAAATCCGAAGTGTAGTCCCACTTGACTGTCAA 180

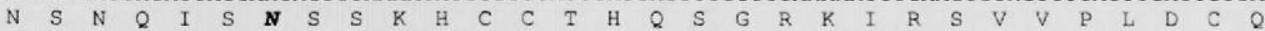

181 CTTGGCCAGTGGGCACAATGGACAGTGTGTTCTCCTTGTGAAGCAAGAAAGTCCAGATATAGGAATCTGAATCGGCCAGCCATATATGGI 270

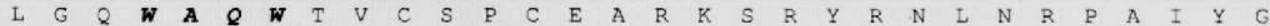

271 GGTAGCCAATGCATTGGATCTCTCTGGGAAGACACATCTTGTGAAACATCTGAACAATGCATACCAAAAATAACTGTGGTGATCAGTTT 360

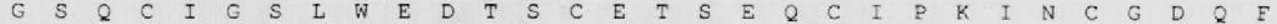

361 CAATGTAGTTCAGGTCGATGTATTAAAAGACATTTACTGTGCAATGGTGAGAAAGACTGTGCAGATGTTTCAGATGAAGAAACCTGTGAG 45O

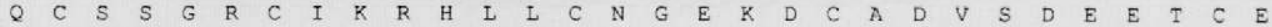

451 TCTGATTATCCATATGAGAGAAGGACTTTCTGCAGTGACTTGTTTTTAATCCCAGGCATAGAAGCAATTATGACTGGCTATAACATCTTA 540

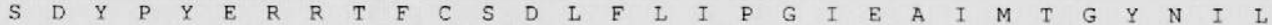

541 ATACATGACGTTGGAAGAACTGTGTTAGACACTGGGTTTGGTGGATATTGTGAATATGTGTATAATGGGGACTGGAGGGAACTGCGATAT 630

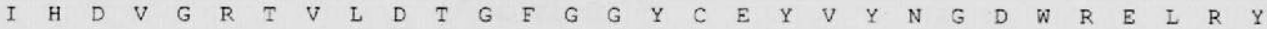

631 GACAGTGAGTGTGAACGCCTCTACTATAACGATGATGAGAAATACTACCGAAAACCATACAATTTACTCACATACCGTTTTGAGGCAATT 720

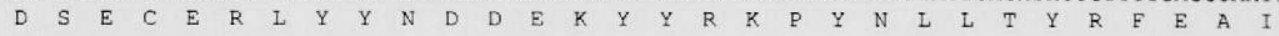

721 GCTGATTCTGGATTTACCATAGATGTTCACAATGATGTACATGAATTAATTACAGCAATGAAGCATACAGACTCCTTTGATTTTGCAGTC 810

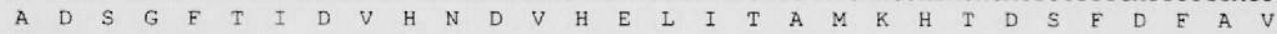

811 GGTGTGCAAGTTTCTGTTGTAAAAGCTGCTATTGCTTTTGGAGAATATTCCACATTTATTAGAAATGTATCAAGGTTTCAAGGGAAGGAT 900

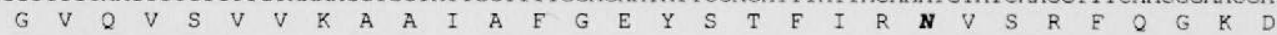

901 GTCAGTTTTGTTCGTGTTCGTACTAAGATTCAAACTGCTCACTTCAAAATGAGGAGATATAATTTACTTTTGGATGAAGATATGACTCAA 990

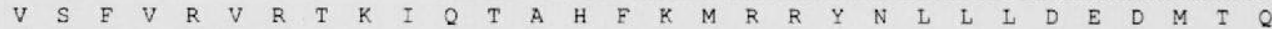

991 TCCCTCATGAAACTTCCAGATGAATACAATTACGGAATGTACGCTAAATTCATTGCAGATTATGGTACTCATTACTATGCTTCAGGAACA 1080

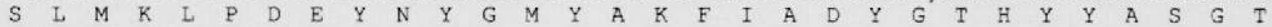

1081 ATGGGAGGTGTTTATGAGTTCATTCTTGTTCTGAATAAGAAGGCATTGGCAGAGTCAGATTTAACTGCATCCGAAGCTGGATTTTGCGTT 1170

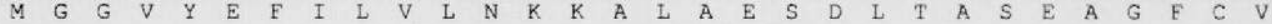

1171 GCAGGATCACTGGGAGTAGTGGTTTCAAAAGGAACCATGGATGTGGGTGGCTCGGTAAAGGCCAAAGGTTGTAGACGTAAATTGGAGCAG 1260

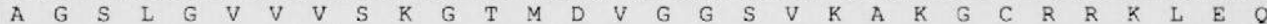

1261 AATGAACCTTCAGAAAAGTCAAGAAGCCTTGTTGAAGATGTTCTTCCACATGTACTGGGAGGTGACCTGAAATCAAGTGCTGGACTATTA 1350

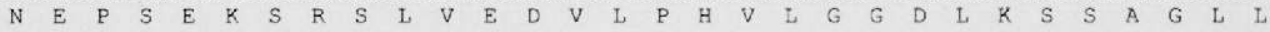

1351 GGTCATGGAATACCAGATGTCAAAATGTATCGGCATTGGGGTAAATCTTTGAAATACCTGCCAGCTGTCATTGACTTTGAGCTCATGCCA 1440

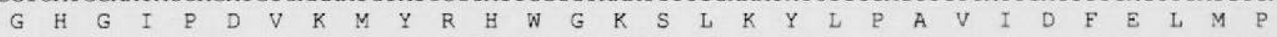

1441 ATTTATGACTTGGTGGCCAGAAGTAAACTTCAGTCTGTTGAAATCAAACAACAAAATTTAAAAAGAGCCATGGAAGAGTACTTGGTGGAG 1530

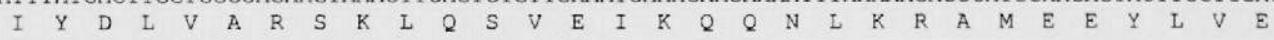

1531 TTTCATCCCTGTAGGTGTCCTGTGTGCTATAATAATGGAAAAGCAGTTCTTCTGGACAATGTCTGTACCTGTGAATGTCTGCCTGGTTAT 1620

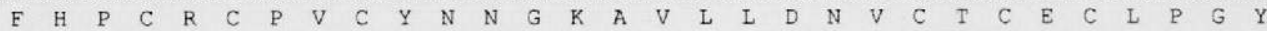

1621 GAAGGGAAAGCGTGCCAGGATACTAAACGAAAGGGGCCCACTAATGGAAATTGGAGCTGTTGGTCAGGGTGGTCTTCTTGCCAGAATGGT 1710

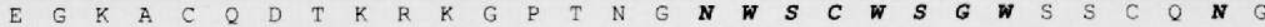

1711 TCAAAACAGCGAACACGAAGCTGTAACCATCCACCCCCTAAAGATGGTGGTGCTACATGCCTTGGGAAGAACACACAAACCAAGCATTGT 1800

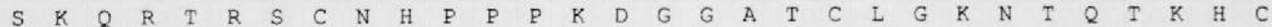

1801 TAAAACAAAATAATACCTCTGGCATTTTGGCCCGTTGAATTATTTGCTTTTGGGTGATCATTATTTTCTTTGAGTATAGATGAATATGAG 1890 1891 GTATAGGCAACATTTTGAAATACTACTCTGTGTTCTTTGTTGATTTCTTAAATGTAATGAATGTTGAGATGTATTCATTGATGTGAAACA 1980 1981 TTTGAACTGACGTGACAAGAATTATCCTTTATTGAAGAAAGATTAAAACTGATTTGTGTGCATTAATGTTTGGCCAGGAAGCTTGTTCAC 2070 2071 ACTTCCAGGACCATCATTACCAGTTGATTGGTCAACATACTGCAATGAATTATGGGAGTCAGCATTGCAATAGACCTCATTGTGATGAAT 2160 2161 ACATGTTGACCTTGATATCTGATCCATTGTTTTCTTTACAGCAGGAACAGAATGGTAGTAAGAAAATATGAAAATCAAATCAATATATTI 2250 2251 AGCAGCATTAAATTCTGTACAGGATATCAAAGCAGTTATGATTCCTATTACTAATAAAGAGATGCCAAAAAAAAAAAAAAAAAAAAAAA 2341

Figure 4. Nucleotide and deduced amino acid sequence of GcC $8 \alpha$ cDNA. The nucleotide sequence is above and the deduced amino acid sequence is below. Underlined bold letters indicate initiation codon, stop codon, and polyadenylation recognition signal, and the polyadenylation tail sequence. Putative N-linked glycosylation sites are indicated by bold, italicized N's and mannosylation sites indicated by bold, italicized sequences beginning and ending with $\mathrm{W}$. 
Table 4. Percent Identity and Similarity between the deduced amino acid GcC $8 \alpha$ sequence and $\mathrm{C} 8 \alpha$ homologues of other taxa

\begin{tabular}{|c|c|c|}
\hline Organism & Identity & Similarity \\
\hline Human & 41.4 & 76.2 \\
\hline Rabbit & 40.9 & 76.9 \\
\hline Chicken & 36.9 & 65.4 \\
\hline Mouse & 42.6 & 78.4 \\
\hline Rat & 40.6 & 72.2 \\
\hline Pig & 44.0 & 77.1 \\
\hline Frog & 47.4 & 77.4 \\
\hline Rainbow Trout & 38.7 & 70.1 \\
\hline
\end{tabular}

Phylogenetic analysis

Multiple alignments for phylogenetic analysis were constructed by the ClustalX program (Thompson et al., 1997) using entire protein sequences of known MAC amino acid sequences, obtained from GenBank (Table 5) and $\mathrm{GcC} 8 \alpha$. This alignment was then used by the PAUP* program (Swafford, 2002) to construct a phylogeny using the neighbor joining algorithm (Saitou and Nei, 1987) under the default settings (Figure 5). Human, mouse, cow, cat and woodchuck perforin sequences were used as an out group. Confidence in the branch points were validated by 1000 bootstrap replications. GcC $8 \alpha$ forms a clade with $\mathrm{C} 8 \alpha$ sequences from other taxa and is sister taxa with Xenopus $\mathrm{C} 8 \alpha$. The tree also shows that the $\mathrm{C} 8$ complex has diverged from a common ancestor with $\mathrm{C} 9$.

Table 5. Accession numbers correlating with sequences used in Figure 6 phylogeny

\begin{tabular}{|l|l|l|l|l|l|}
\hline Organism & $\begin{array}{l}\text { Accession } \\
\text { number }\end{array}$ & Organism & $\begin{array}{l}\text { Accession } \\
\text { number }\end{array}$ & Organism & $\begin{array}{l}\text { Accession } \\
\text { number }\end{array}$ \\
\hline Human C6 & BAD02321 & Mouse C7 & XP_356827 & Rabbit C8 $\alpha$ & AAA31191 \\
\hline Trout C6 & CAF22026 & Human C8 $\alpha$ & NP_000553 & Chicken C8 $\alpha$ & XP_426667 \\
\hline Frog C6 & AAH76972 & Trout C8 $\alpha$ & CAH65481 & Xenopus C8 $\alpha$ & AAH74554 \\
\hline $\begin{array}{l}\text { Amphioxus } \\
\text { C6 }\end{array}$ & BAB47147 & Chimpanzee C6 & $\begin{array}{l}\text { NP_00100901 } \\
5\end{array}$ & Zebrafish C9 & $\begin{array}{l}\text { NP_001019 } \\
606\end{array}$ \\
\hline
\end{tabular}




\begin{tabular}{|l|l|l|l|l|l|}
\hline Human C7 & CAA60121 & Dog C6-1 & XP_868028 & Human C8 $\alpha$ & NP_000553 \\
\hline Trout C7-1 & CAD92841 & Dog C6-2 & XP_536488 & Human C8 $\beta$ & NP_000057 \\
\hline Trout C7-2 & CAF22025 & Rat C7 & XP_226803 & Cow C8 $\beta$-1 & XP_590870 \\
\hline Chicken C6 & XP_429140 & Chicken C7 & XP_424774 & Cow C8 $\beta$-2 & XP_870144 \\
\hline Xenopus C6 & AAH76972 & Flounder C7 & BAA88899 & Dog C8 $\beta$ & XP_536694 \\
\hline Zebrafish C6 & NP_956932 & Shark C8 $\alpha$ & EF654112 & Mouse C8 $\beta$ & NP_598643 \\
\hline Pig C7 & NP_999447 & Trout C8 $\beta$ & AAL16647 & Flounder C8 $\beta$ & BAA86877 \\
\hline Human C9 & NP_001728 & Trout C9 & P06682 & Fugu C9 & AAC60288 \\
\hline Rat C9 & NP_476487 & Mouse C9 & NP_038513 & Grass Carp C9 & AAS76086 \\
\hline Trout C9 & CAJ01692 & Killifish C9 & AAR87007 & Flounder C9 & BAA86878 \\
\hline Dog C9 & XP_536494 & Human perforin & AAA60065 & Orangutan C6 & BAD02323 \\
\hline $\begin{array}{l}\text { Flounder } \\
\text { perforin }\end{array}$ & BAC76420 & & & & \\
\hline
\end{tabular}

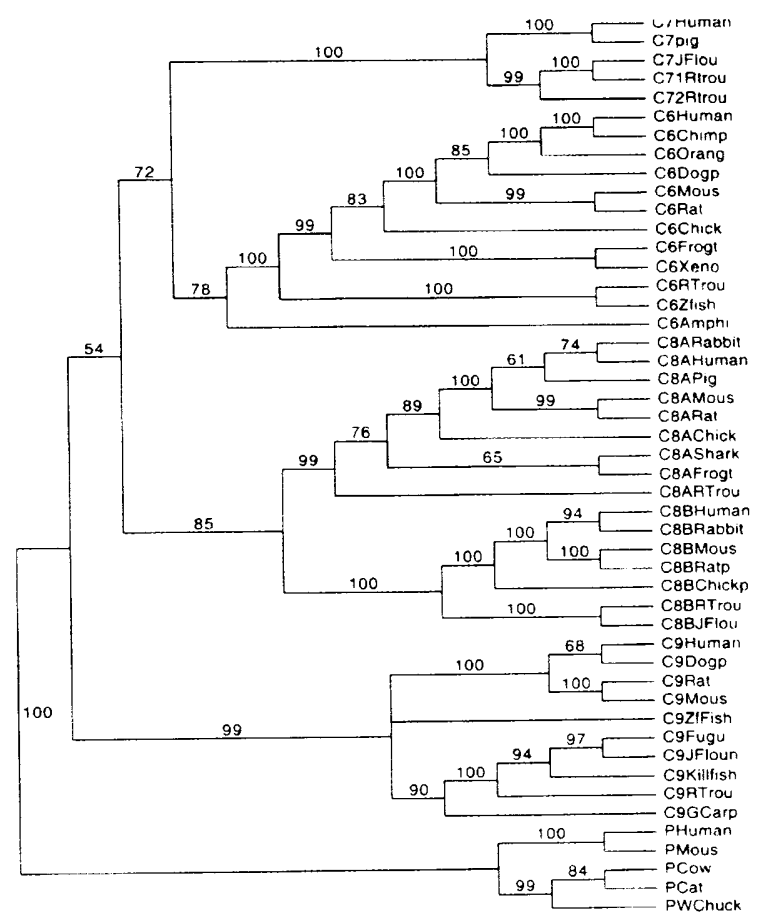

Figure 5. Phylogenetic analysis of MAC amino acid sequences across taxa. Alignment completed in ClustalX and phylogenetic tree generated by PAUP rooted on perforin from three taxa. Accession numbers of the sequences used to construct the tree are listed in the Table 5. 
Multiple Alignment and Sequence Analyses

Using the computer software ClustalW, the shark $\mathrm{C} 8 \alpha$-deduced amino acid sequence was aligned with other $\mathrm{C} 8 \alpha$ amino acid sequences of human, mouse, xenopus, and trout (Figure 6). The shark C8 $\alpha$ sequence contains 33 cysteine residues of which 29 are conserved between the shark and human sequences. These residues are potentially capable of forming, through disulfide bonds, the characteristic C $8 \alpha$ cysteine backbone suggesting a similar folding pattern and function to mammalian, amphibian, and teleost $\mathrm{C} 8 \alpha$. The $\mathrm{GcC} 8 \alpha$ sequence includes the cysteine residue at 164 in human $\mathrm{C} 8 \alpha$ and forms the disulfide bond with $\mathrm{C} 8 \gamma$ (Brickner and Sodetz, 1985). The nurse shark $\mathrm{C} 8 \alpha$ sequence also conserves the cysteines that correspond to $\mathrm{C}^{324}$ and $\mathrm{C}^{349}$ in human that are proposed to form a disulfide bridge (Peitsch et al., 1990) (Figure 6). The multiple alignment also confirms the presence of the indel (human aa 159-175, shark aa 198-207) exclusive to $\mathrm{C} 8 \alpha$ (Figure 6 and 7).

Analysis of the primary structure showed that $\mathrm{GcC} 8 \alpha$ has a modular structure consistent with that of $\mathrm{C} 8 \alpha$ of other taxa examined (Figure 8). The MAC-conserved modules identified in $\mathrm{GcC} 8 \alpha$ are similar to those of mammalian species. The two T1 repeats, LA repeats, EG, and MACPF segments are present in $\mathrm{GcC} 8 \alpha$ and are highly conserved (Figure 6 and 8).

Two potential N-linked glycosylation sites, at $\mathrm{ASN}^{26}$ (in the 5' UTR) and $\mathrm{ASN}^{281}$ (Figures 4 and 8), were identified in the sequence. The sequence was also examined for potential mannosylation sites; two were identified: one in the first $\mathrm{T} 1$ repeat in the pattern of WxxW amino acids 532-565 WAQW and the second site in the WxxWxxW motif and 


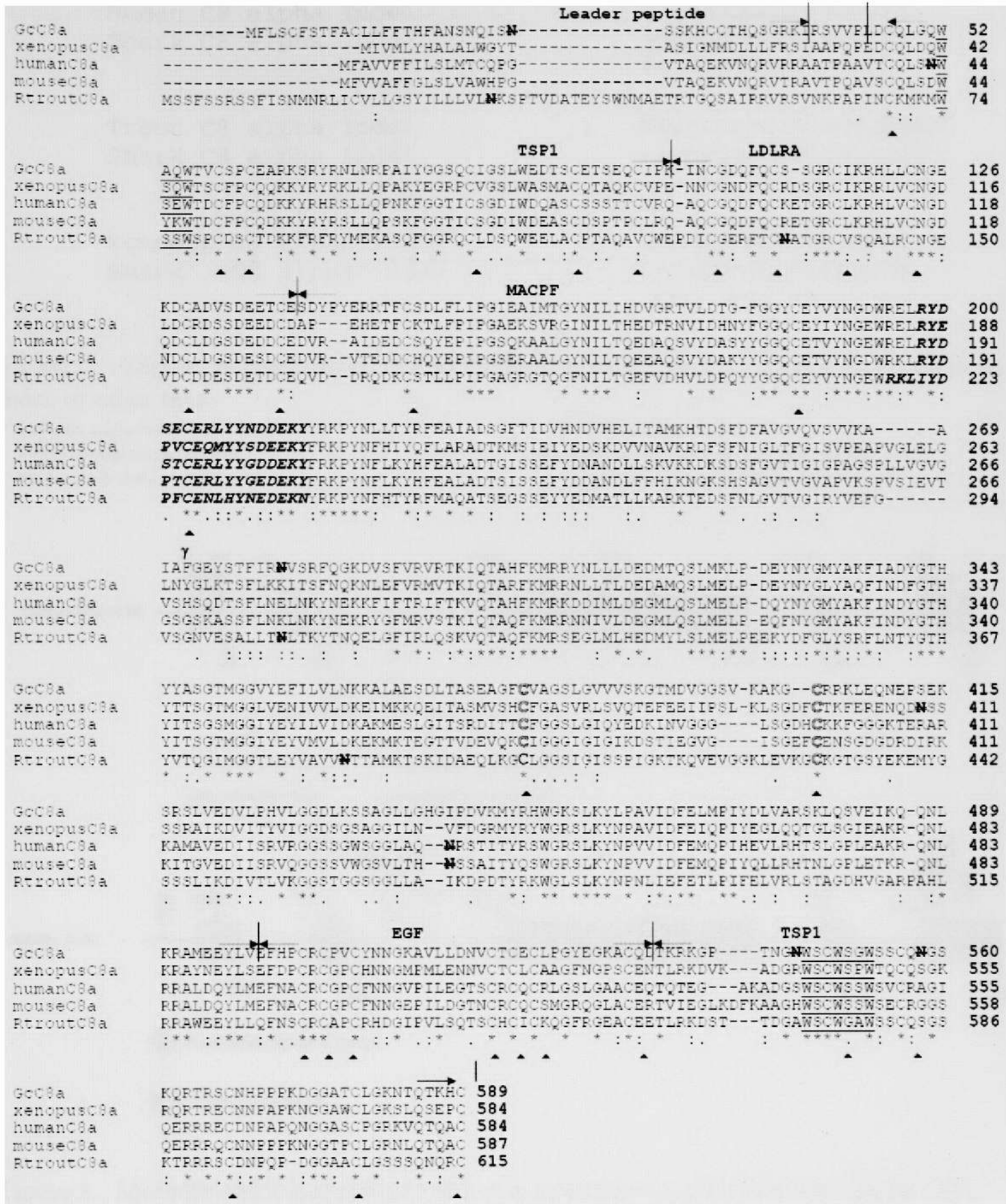

Figure 6. Full-length amino acid sequence alignment in ClustalW of GcC8 $\alpha$ with homologues from other vertebrates: Homo sapiens, Mus muluscus, Xenopus tropicalis, and Oncorhynchus mykiss. The two conserved cysteine residues that are predicted to form a di-sulfide bridge and the indel sequence are highlighted in bold italics.

Legend:

* residues conserved in all six proteins

: strong group conservation

weak group conservation

y C8y disulfide bond

putative $\mathrm{N}$-linked glycosylation sites

- cysteines conserved between mammalian $\mathrm{C} 8 \alpha$ and $\mathrm{GcC} 8 \alpha$ 
Human C8 alpha Indel

Shark C8 alpha Indel

Trout C8 alpha Indel

Shark C8 alpha Indel

Xenopus C8 alpha Indel

Shark C8 alpha Indel
RYDSTCERLYYGDDEKY

RYDSECERLYYNDDEKY

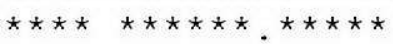

RKLIYDPFCENLHYNEDEKN

---RYDSECERLYYNDDEKY

${ }^{*} . * * .{ }^{*}: * \star * * * *$

RYEPVCEQMYYSDEEKY

RYDSECERLYYNDDEKY

${ }^{*}: . * *:: * * . *: * * *$

Figure 7: Alignment comparison of shark $\mathrm{C} 8 \alpha$ insertion/deletion sequences (indel) with those of other taxa

* residues conserved in all six proteins

: strong group conservation

. weak group conservation

$\gamma \mathrm{C} 8 \gamma$ disulfide bond

A putative $\mathrm{N}$-linked glycosylation sites

_ putative C-mannosylated sites

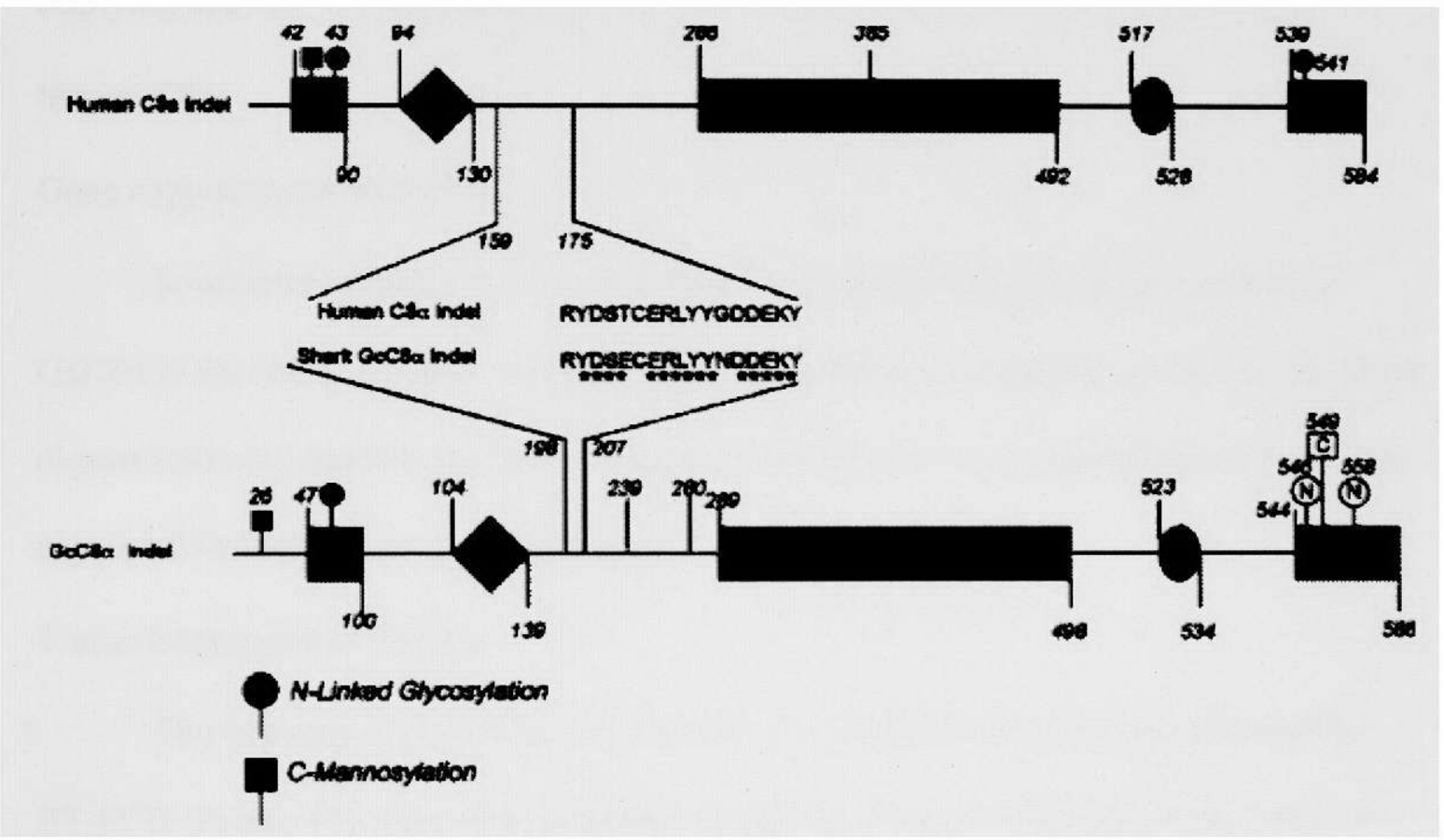

Figure 8. Modular and Glycosylation site map comparison of Human and Shark C8 $\alpha$. Schematic representation of the organization of modules/domains 5' -3 ' direction in $\mathrm{GcC} 8 \alpha$ shows it to be similar to that of human $\mathrm{C} 8 \alpha$ in domain architecture: $\mathrm{T} 1$ repeats $(\boldsymbol{\square}), \mathrm{LA}(\mathrm{)}), \mathrm{MACPF}(\square)$, and an epidermal growth factor region (O). Potential Nlinked glycosylation sites are featured as stalkcircle with an $\mathrm{N}$ and predicted $\mathrm{C}$ mannosylation sites have a C. The $\mathrm{GcC} 8 \alpha$ indel was aligned in ClustalW with the human $\mathrm{C} 8 \alpha$ indel. Asterisk $\left({ }^{*}\right)$ denote residue identity and period (.) indicate similar residues. 
located toward the end of the sequence in the final $\mathrm{T} 1$ repeat domains at amino acids 547553 in the shark sequence in the pattern of WSCWSGW (Hofsteenge et al., 1999).

A Kyte and Doolittle (1982) hydrophobicity analysis comparing $\mathrm{GcC} 8 \alpha$ to human $\mathrm{C} 8 \alpha$ was made in the BioEdit program (Hall, 1999); the results are shown in Figure 9. The GcC $8 \propto$ hydrophobicity profile suggests consistent similarities in the hydrophobic regions with the exception of regions spanning amino acids 140-190 which lies between the LA and MACPF modules, and amino acid stretches 380-395 and 462-470 within the MACPF domain. These amino acid stretches are more hydrophobic in the shark implying that $\mathrm{GcC} 8 \alpha$ has the ability to traverse a membrane in a similar fashion as human $\mathrm{C} 8 \alpha$.

Gene copy analysis of $\mathrm{GcC} 8 \alpha$

Southern blot analysis was performed to determine the gene copy number of GcC $8 \alpha$ in the shark genome. A single hybridizing band was detected in each of the DNA digests (enzyme digestion by BamHI, EcoRI, HindIII, and PstI), indicating a single gene copy of $\mathrm{C} 8 \alpha$ in the shark genome (Figure 10).

Tissue Expression of $\mathrm{GcC} 8 \alpha$

The expression of GcC $8 \alpha$ mRNA in tissues of the nurse shark was detected by RT-PCR (Figure 11). This semi-quantitative analysis revealed distinctly high levels of GcC $8 \alpha$ transcripts in the liver, which is the primary tissue of complement protein synthesis in most organisms. The level of expression was similar to that of the $\beta$-actin control. GcC $8 \alpha$ synthesis, albeit at lower levels, was detected in all tissues examined (kidney, brain, intestine, ovary, muscle, heart, pancreas, erythrocytes, and leukocytes), 
except for the spleen, where no expression was detected. This semi- quantitative analysis shows that nurse shark muscle tissue and erythrocytes have the highest levels of $\mathrm{GcC} 8 \alpha$ synthesis after liver and smaller amounts in kidney, brain, intestine, ovary, heart, pancreas, and leukocytes. $\beta$-actin expression, included as a positive control, was relatively uniform in all tissues examined.

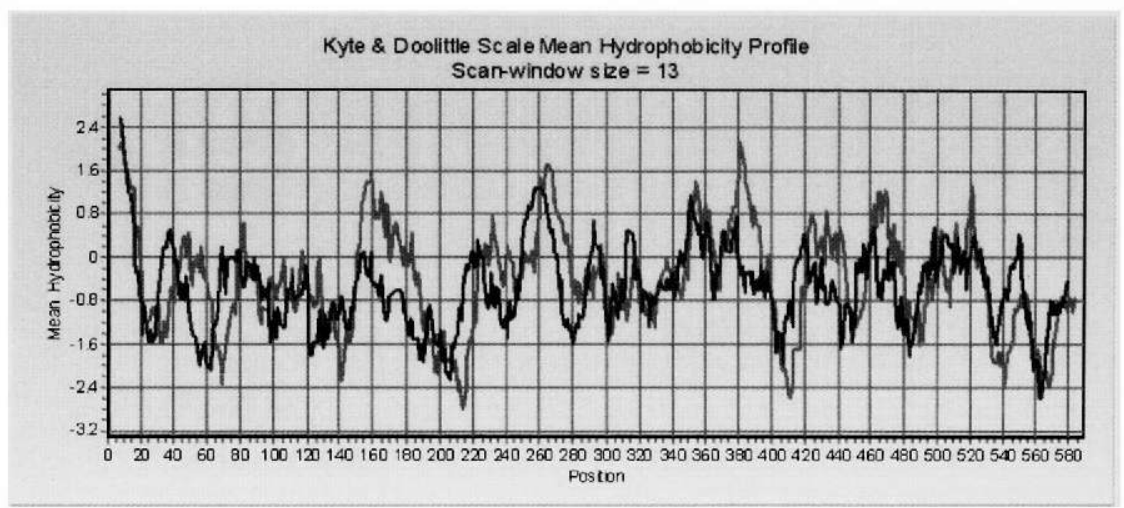

Figure 9: Molecular analysis: Hydrophobicity profile of shark $\mathrm{C} 8 \alpha$ (grey) and human C8 $\alpha$ (black) using the Kyte \& Doolittle scale computed in the BioEdit program Western Blot Analysis

Western blots were used to determine, using cross-reactive antibodies, the presence in shark serum of proteins analogous to mammalian MAC proteins. Blots were developed using goat anti-human sera to $\mathrm{C} 6, \mathrm{C} 7, \mathrm{C} 8$, and $\mathrm{C} 9$ as the primary antibody. The secondary antibody was a rabbit anti-goat tagged with HRP.

Western blot using Anti-human C9 antisera

The Western blot using goat anti-human C9 (Figure 12) as the primary detection antibody revealed reactive bands above $250 \mathrm{kDa}$ under reducing $(\mathrm{R})$ and non-reducing 
(NR) conditions. This could possibly be due to cross-reactivity between the anti-human C9 antibody and aggregated poly-C9 of SC5b-9. There was also a reactive band at 71

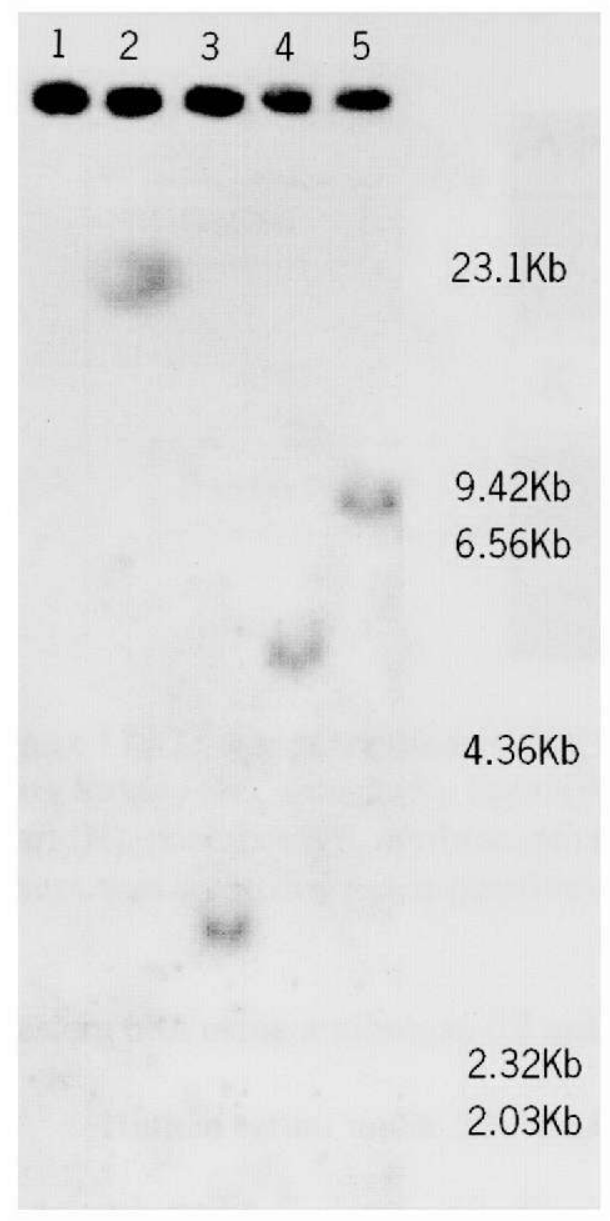

Figure 10. Southern blot analysis. Genomic DNA from shark whole blood was isolated and digested with the restriction enzymes, BamH I (Lane 2), EcoRI (Lane 3), HindIII (Lane 4), and PstI (Lane 5), electrophoresed, transferred to a nylon membrane and subjected to hybridization with a DIG- labeled probe. A lambda DNA/Hind III-digests DNA mass marker was run in lane 1, the scale is displayed to the right of the blot.

$\mathrm{kDa}$ in human serum under both reducing and non-reducing conditions, which corresponds to the molecular weight of human C9. In addition, in the reduced sample of human serum a band at $\sim 40 \mathrm{kDa}$ was detected. Reduced and non-reduced samples of 
shark serum and supernatant 1 showed bands at $49 \mathrm{kDa}$ and in the NR shark serum sample a band at $68 \mathrm{kDa}$ was revealed which may correspond to shark $\mathrm{C} 9$, suggesting that that the shark molecule is slightly smaller than the human homologue.

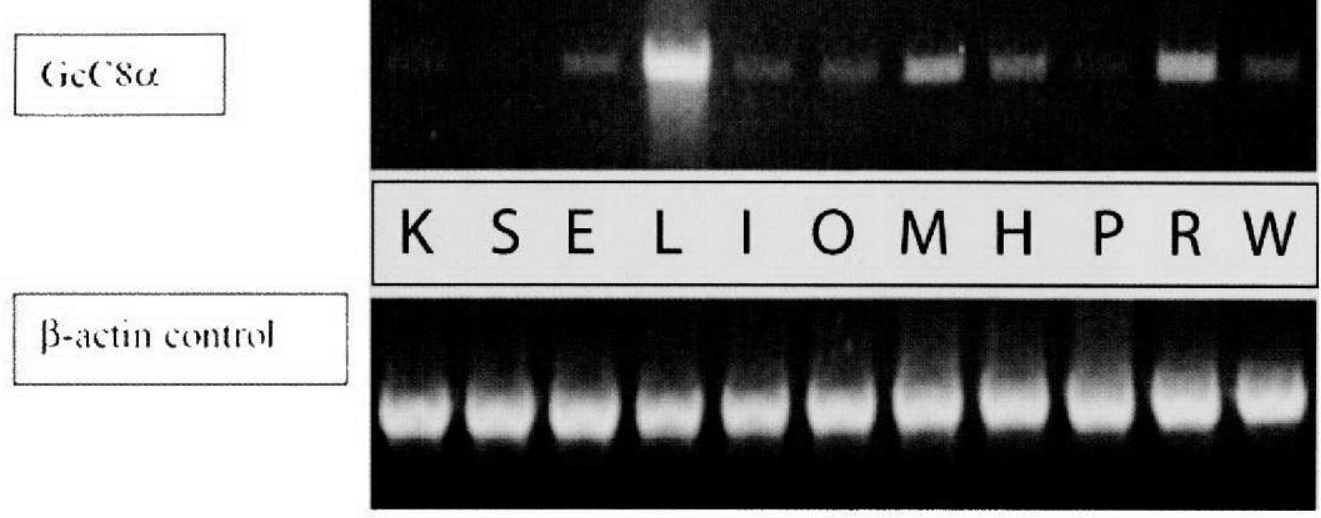

Figure 11. Tissue expression of $\mathrm{GcC} 8 \alpha$. RT-PCR analysis of $\mathrm{GcC} 8 \alpha$ expression in shark kidney $(\mathrm{K})$, spleen $(\mathrm{S})$, brain $(\mathrm{B})$, liver $(\mathrm{L})$, intestine $(\mathrm{I})$, ovary $(\mathrm{O})$, muscle $(\mathrm{M})$, heart $(\mathrm{H})$, pancreas $(\mathrm{P})$, erythrocytes $(\mathrm{E})$, and leukocytes $(\mathrm{L})$. Expression of $\beta$-actin in tissues was amplified as the positive control.

Western blot using antihuman C8 antiserum

Human serum under NR conditions showed a band at $151 \mathrm{kDa}$, which represents the human $\mathrm{C} 8$ trimer. Two bands were also detected in the non-reduced human serum sample at 60 and $62 \mathrm{kDa}$ that most likely represent $\mathrm{C} 8 \alpha$ and $\beta$ subunits. Therefore, under NR conditions, the full oligomer was detected along with its individual $\alpha$ and $\beta$ counterparts. Under reducing conditions, there were two bands at 60 and 62 for the $\alpha$ and $\beta$ components of human C8. Adding DTT reduced the oligomer completely to its $\alpha$ and $\beta$ counterparts. In the lanes with shark serum and spt1, both under-reducing and nonreducing conditions, a faint band was present at $64 \mathrm{kDa}$, signifying either $\mathrm{GcC} 8 \alpha$, a $\mathrm{C} 8 \beta$ 
-like component, or possibly both, since in mammals they are of similar size. Under the NR conditions, a faint band is seen at $\sim 185 \mathrm{kDa}$ in all lanes with shark protein.

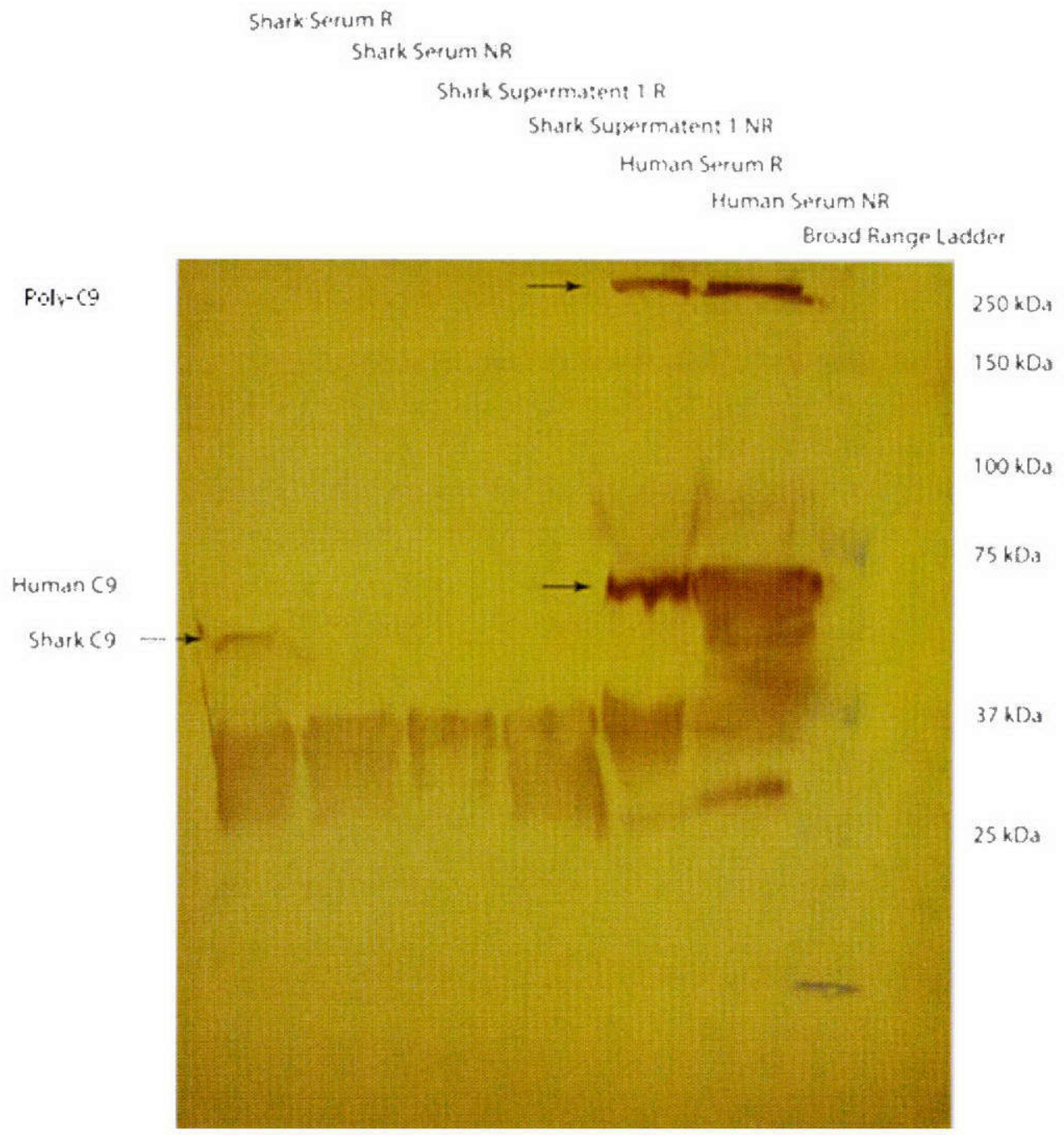

Figure 12. Western blot of $\mathrm{C} 9$ using whole shark serum, shark supernatent 1 , and human serum samples under reducing $(R)$ and non-reducing $(N R)$ conditions. The blot was developed using a goat anti-human $\mathrm{C} 9$ primary antibody and peroxidase-tagged rabbit anti-goat Ig secondary antibody. 
Western blot using antihuman $\mathrm{C} 7$ antiserum

The Western blot yielded a single band for human serum at $110 \mathrm{kDa}$ representing human C7 under NR conditions. Since C7 is a single polypeptide a corresponding band was expected to be present in the reduced human serum sample which was not the case.

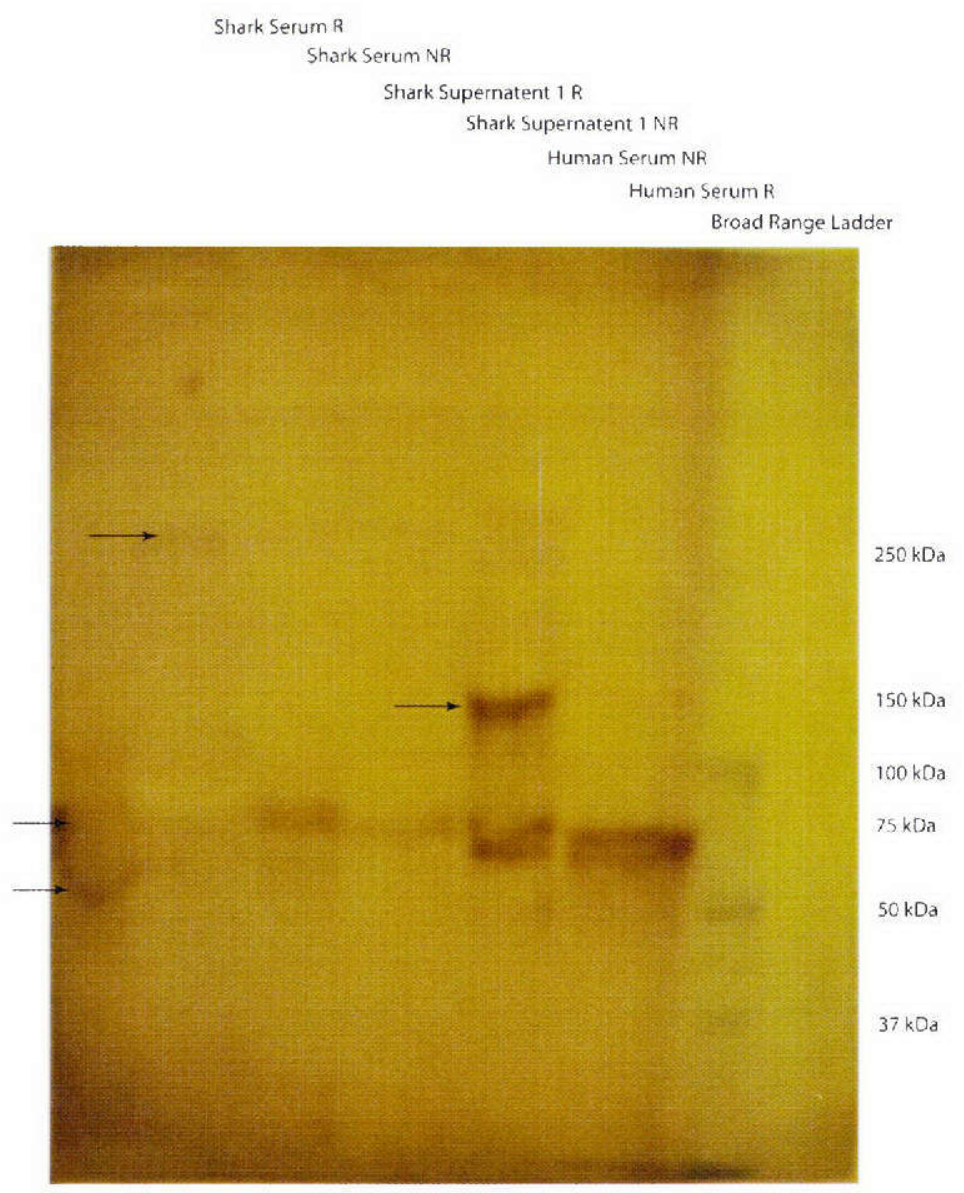

Figure 13. Western blot of C8 using whole shark serum, shark supernatent 1 , and human serum samples under reducing $(\mathrm{R})$ and non-reducing $(\mathrm{NR})$ conditions. The blot was developed using a goat anti- human $\mathrm{C} 8$ primary antibody and peroxidase-tagged rabbit anti-goat Ig secondary antibody.

It is possible that DTT (the reducing reagent) may have reduced intra-protein disulfide bond(s) that changed the conformation of human $\mathrm{C} 7$ protein, obscuring the epitope that the anti-human $\mathrm{C} 7$ antibody would recognize. Furthermore, no reactive bands appeared 
in any of the shark samples suggesting that either the antibody did not recognize and cross-react with a corresponding C7-like shark protein or a C7 homologue is absent in shark serum.

Western blot using anti-human C6 antiserum:

Western blot analysis of human serum, shark serum, and shark supernatant 1 using polyclonal anti-human C6 antiserum yielded no detectable bands in any of the samples run, including human serum. No reactivity with human serum was unexpected and might have been due to the dilution of the primary and secondary antisera in which the concentration of antibodies was insufficient to produce a detectable reaction.

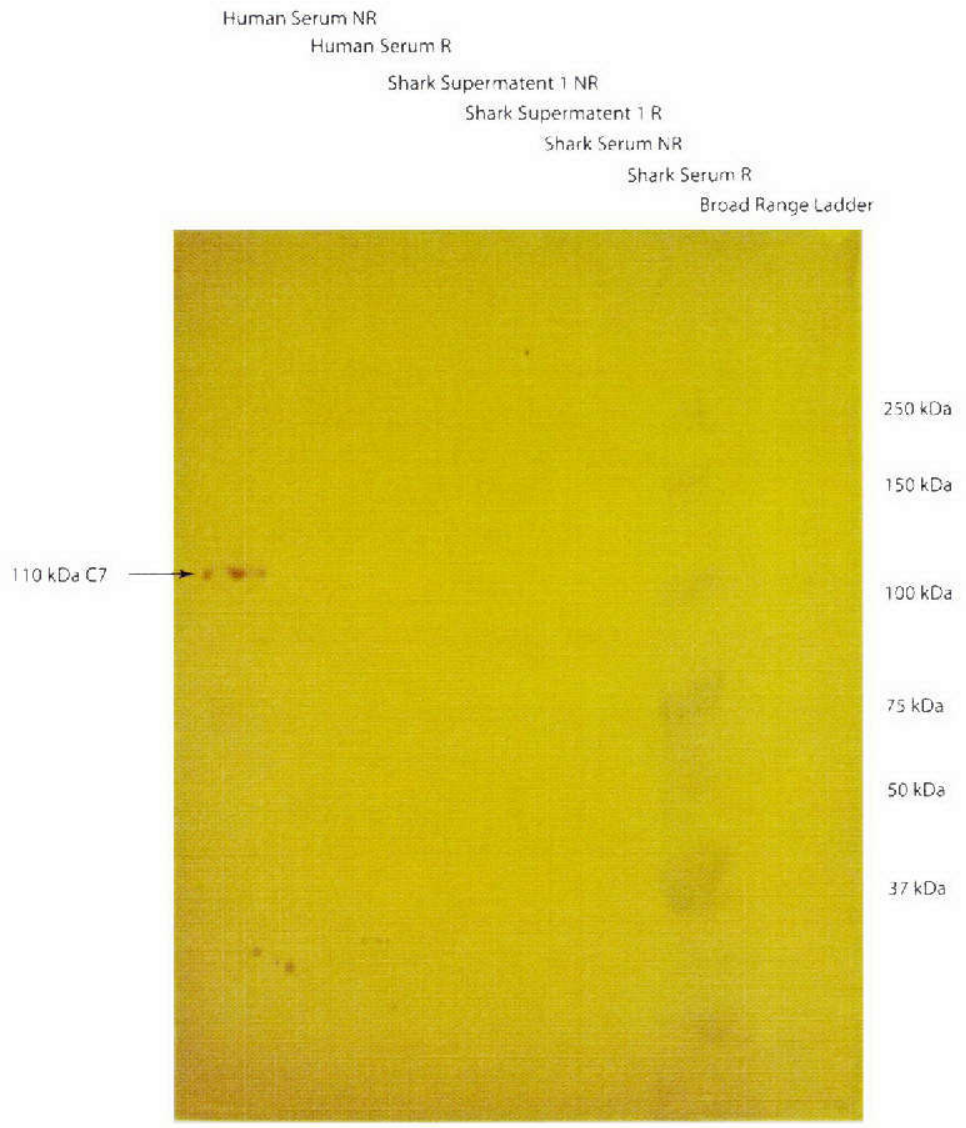

Figure 14. Western blot of $\mathrm{C} 7$ using whole shark serum, shark supernatent 1 , and human serum samples under reducing $(\mathrm{R})$ and non-reducing $(\mathrm{NR})$ conditions. The blot was 
developed using a goat anti-human C7 primary antibody and peroxidase-tagged rabbit anti-goat Ig secondary antibody. 


\section{CHAPTER V.}

\section{DISCUSSION}

This study is based on the hypothesis that the lytic activity of shark serum is due to the presence of a functional lytic pathway that assembles a membrane attack complex similar to mammalian MAC even though in the shark, it may be executed differently due to different composition. Since there is no evidence of complement lysis and/or MAC genes or proteins corresponding to $\mathrm{C} 6$ and $\mathrm{C} 7$ in any organisms more basal than teleosts, the question remained what was the composition of shark MAC and whether it involved molecules corresponding to $\mathrm{C} 6$ and $\mathrm{C} 7$. This initial study focused on the $\mathrm{C} 8 \alpha$ subunit of shark $\mathrm{C} 8$ as a first step to define shark MAC and further our understanding of the evolution of this protein complex. Furthermore, evidence was sought to determine whether $\mathrm{C} 6$ and $\mathrm{C} 7$ homologues could be detected in shark serum. The shark $\mathrm{C} 8 \alpha$ gene was cloned, sequenced, and characterized. Western blot analysis was performed to examine shark serum for the presence of potential $\mathrm{C} 6, \mathrm{C} 7, \mathrm{C} 8$ and $\mathrm{C} 9$ homologues.

Here we report in detail the first nucleotide and deduced amino acid sequence of a full-length cDNA clone of a shark MAC gene homologus to C8 $\alpha$ (Figure 4). The gene encoding the shark $\mathrm{C} 8 \alpha$ homologue ( $\mathrm{GcC} 8 \alpha$ ) was cloned and yielded a 2431 nucleotide sequence complete with initiation codon, stop codon, polyadenylation recognition signal, and the polyadenylation tail sequence (Figure 4).

The cloned GcC $8 \alpha$ sequence translated into a 589 amino acid sequence (Figure 4 and 6) that exhibits $41.3 \%$ identity (Table 4 ) with human $C 8 \alpha$ and has the highest percent identity with the frog $\mathrm{C} 8 \alpha$ sequence ( $47.4 \%$ ). Phylogenetically, $\mathrm{GcC} 8 \alpha$ is sister taxa to 
frog $\mathrm{C} 8 \alpha$ and that teleost $\mathrm{C} 8 \alpha$ is more basal to both these genes, confirming that shark $\mathrm{C} 8 \alpha$ is more like that of the frog than bony fish (Figure 5). The shark $\mathrm{C} 8 \alpha$ sequence has more identity with mammalian (mouse $-42.6 \%$ and pig - $44.0 \%$ ) and frog $\mathrm{C} 8 \alpha$ sequences than to trout $(38.7 \%)$. The shark $\mathrm{C} 8 \alpha$ sequence shares the lowest sequence identity and similarity to chicken $\mathrm{C} 8 \alpha-36.9 \%$ and $65.4 \%$, respectively. In terms of similarity, it was surprising that the $\mathrm{GcC} 8 \alpha$ sequence exhibited the highest similarity to a mammalian sequence, mouse $\mathrm{C} 8 \alpha$, at $78.4 \%$, and had the next highest percent similarity to frog and pig $\mathrm{C} 8 \alpha, 77.4 \%$ and $77.1 \%$, respectively.

Alignments of the deduced $\mathrm{GcC} 8 \alpha$ sequence reveal conservation of modules that are characteristic to the MAC protein family. Structural analysis reveals that the MAC modular architecture is conserved and organized in the same sequential order as mammalian MAC proteins, specifically T1 (aa 47-100), LA (aa 104-139), MACPF (aa 289-498), EG (aa 523-534), and a final T1 (aa 544-588) module (Figure 8).

$\mathrm{C} 8 \alpha$ is a unique member of MAC in that it contains an indel site that contains the

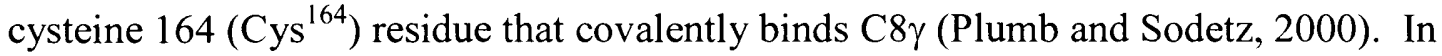
humans, the indel region is the sequence that $\mathrm{C} 8 \gamma$ associates with, even when $\mathrm{Cys}^{164}$ is replaced by a glycine residue, meaning that there is sufficient biochemical attraction in the indel amino acid composition to bind C8 $\gamma$ non-covalently (Plumb and Sodetz, 2000). Multiple alignment (Figure 6) shows that the corresponding $\mathrm{Cys}^{164}$ as well as the region corresponding to human indel is conserved, which indicates that $\mathrm{GcC} 8 \alpha$ is a $\mathrm{C} 8 \alpha$ ortholog and shark is the most basal organism to have this unique sequence. The shark indel (aa 198-207) is located between the LA and the MACPF domain and contains the 
conserved cysteine residue at position 203 , suggesting that $\mathrm{GcC} 8 \alpha$ may occur as a disulfide-linked $\alpha-\gamma$ dimer. This region is highly conserved between human and shark (Figure 6-8), with $88.2 \%$ identity and $94.1 \%$ similarity to the human indel sequence. This conservation of structural similarity as well as high conservation of the sequence responsible for the non-covalent binding to the $\mathrm{C} 8 \beta$ subunit further suggests that $\mathrm{GcC} 8 \alpha$ might work as a trimer as C8 does in other organisms. It should be noted, however, that homologues of $C 8 \beta$ and $C 8 \gamma$ have yet to be described in the shark.

In humans, it has been demonstrated that all MAC proteins and perforin have two conserved cysteine residues (C7: $\mathrm{Cys}^{317}$ and $\mathrm{Cys}^{333}, \mathrm{C} 9: \mathrm{Cys}^{358}$ and $\mathrm{Cys}^{383}, \mathrm{C} 8 \mathrm{a}:{ }^{346}$ and $\mathrm{Cys}^{370}, \mathrm{C} 8 \mathrm{~b}: \mathrm{Cys}^{324}$ and $\mathrm{Cys}^{349}$, perforin: $\mathrm{Cys}^{236}$ and $\mathrm{Cys}^{258}$ ) that form a disulfide bridge. The loop formed by this bond is suspected to be outside the membrane when human MAC is inserted into the target cell (Peitsch et al, 1990). These two pertinent cysteine residues are present in $\mathrm{GcC} 8 \alpha$ (highlighted in black in Figure 6) and suggest a similar functional role.

All cysteine residues of human $\mathrm{C} 8 \alpha$ form intra-molecular disulfide bonds with the exception of $\mathrm{Cys}^{164}$, which forms an intermolecular disulphide bond with $\mathrm{Cys}^{40}$ in C8y (Slade et al, 2006). The MAC proteins are rich in cysteine residues, and the multiple alignment (Figure 6) demonstrates that a total of 29 cysteines are conserved between elasmobranch and mammal suggesting that $\mathrm{GcC} 8 \alpha$ potentially capable of forming, through disulfide bonds, the characteristic $\mathrm{C} 8 \alpha$ cysteine backbone suggesting a similar folding pattern and function to mammalian, amphibian, and teleost $\mathrm{C} 8 \alpha$. GcC $8 \alpha$, however, is more cysteine-rich as it has four extra cysteine residues located toward the N- 
terminal of the sequence in the leader peptide region that are not likely to be involved in $\mathrm{GcC} 8 \alpha$ function.

Examining potential glycosylation conservation in $\mathrm{GcC} 8 \alpha$ is interesting for two reasons: 1). Conservation of glycosylation sites between evolutionarily distant creatures can help confirm that $\mathrm{GcC} 8 \alpha$ is indeed the shark $\mathrm{C} 8 \alpha$ homolog and 2) gylcosylation plays an important role in biological activity, because elements like glycan location can play a role in protein folding and signal response and they structurally can interfere with activation site exposure (Wells et al., 2001). The GcC8 $\alpha$ sequence contains two putative N-linked glycosylation sites, identified at positions different from that of mammalian $\mathrm{C} 8 \alpha$ which has two potential $\mathrm{N}$-linked glycosylation sites, at $\mathrm{ASN}^{51}$ and $\mathrm{ASN}^{385}$. In humans, the latter is the only one suspected to actually be glycosylated (Morley and Walport, 2000). The shark sites are upstream of those in human $\mathrm{C} 8 \alpha$ in amino acid number due to the difference in length between shark and human $C 8 \alpha$; however, the shark glycosylation site is likely analogous to the human one in that the region it is in is conserved and is in the same module. The first potential N-linked glycosylation site in human $\mathrm{C} 8 \alpha$ is located in the T1 module, whereas in the shark it is absent from any module and is present in the sequence upstream of that module in the 5' UTR region and, therefore, is probably not of functional significance. The second N-linked glycosylation site for both human and shark is located in the perforin-like segment, which has very high sequence conservation between mammal and shark. Two potential C-mannosylation sites were identified in the shark $\mathrm{C} 8 \alpha$ sequence in the $\mathrm{T} 1$ repeats and are highly conserved in all orthologs examined (Figure 6 and 8): WAQW (aa 53-56) located in the first T1 
module and WSCWSGW (aa 547-553) in the second T1 module at the C-terminal end of the molecule. As stated above, the location and distribution of glycans in the molecule is important since glycosylation can contribute to protein folding and signal response (Wells et al., 2001).

Based on the size of the coding region and not accounting for potential glycosylation of GcC $8 \alpha$, the predicted molecular weight is likely to be higher than that of human $\mathrm{C} 8 \alpha$ (589 aa versus 554 amino acid residues, respectively), which also has fewer potential N-linked glycosylation sites. Shark $\mathrm{C} 8 \alpha$ also contains a mannosylation site that is absent in the human molecule. An earlier study (Jensen et al., 1981) estimated, from partially purified shark $\mathrm{C} 8$, a molecular weight closer to $185 \mathrm{kDa}$; human $\mathrm{C} 8$ mature protein is $152 \mathrm{kDa}$. However, the structural differences noted could account for the higher estimated molecular size of shark C8. It is also possible that the $\mathrm{C} 8 \gamma$ homologue in shark is a larger molecule contributing to the overall higher molecular size of shark C8.

Comparing the hydrophobicity profile of $\mathrm{GcC} 8 \alpha$ with that of human $\mathrm{C} 8 \alpha$ shows consistent similarities in the hydrophobic regions with the exception of regions spanning amino acids 140-190 which lies between the LA and MACPF modules, and amino acid stretches 380-395 and 462-470 within the MACPF domain. The distribution and position of hydrophobic regions through the entire coding region reveal that $\mathrm{GcC} 8 \alpha$ has the physico-chemical properties to function in a manner similar to $\mathrm{C} 8 \alpha$; that is, it most likely participates in hydrophilic-amphiphilic transition and contributes to the assembly and anchoring of a MAC-like macromolecule into target membranes. These amino acid stretches are more hydrophobic in the shark implying that $\mathrm{GcC} 8 \alpha$ has the ability to traverse a membrane. Although there are small differences in the hydrophobicity profiles 
of human and shark $\mathrm{C} 8 \alpha$, complement of both species still achieves MAC lysis. The lesions formed by shark MAC are smaller in diameter than those formed by mammalian MAC. Mammalian MAC lesions are 100 Angstroms in diameter. Membrane holes produced by shark MAC are 80 Angstroms in diameter, i.e., a difference of 20 Angstroms. However, ultra-structural studies of shark MAC lesions show them to be indistinguishable from those made by guinea pig complement (Jensen et al., 1981).

To assess gene copy of $\mathrm{GcC} 8 \alpha$, Southern blot analysis was performed. $\mathrm{GcC} 8 \alpha$ exists as a single gene in the shark. Since $\mathrm{C} 8 \alpha$ and $\mathrm{C} 8 \beta$ of mammals and other vertebrate species (teleosts) are very similar in sequence homology, extra care was taken to design a Southern blot probe to correspond to a region of $\mathrm{C} 8 \alpha$ that did not overlap with any sequence in $C 8 \beta$ (should such a homologue be present in the shark) to ensure that the Southern blot data reflects gene copy of $\mathrm{GcC} 8 \alpha$ only. In several teleost species, some complement genes are present in several isoforms (Kato et al., 2003; Kuroda et al, 1996; Nakao et al., 2002; 1998; Sunyer et al., 1996, 1997,1998; Chondrou et al., 2008; Gongora et al., 1998; Papanastasiou and Zakardis, 2005; Papanastasiou et al, 2007). This may be due to a suspected third round of genome duplication occurring during the emergence of bony fish (Ohno, 1970). Similarly, in elasmobranchs certain complement genes are present in multiple forms, such as $\mathrm{GcC} 3-1$ and $\mathrm{GcC} 3-2$ (Smith, unpublished); $\mathrm{GcBf} / \mathrm{C} 2-1$ and 2 (Shin et al., 2007); and GcIf-1, $-2,-3$ and -4 (Shin et al., 2009) in the nurse shark and TrscBf-A and -B in the banded houndshark (Triakis scyllia) (Terado et al., 2001; 2002). Thus far there has been no evidence of MAC genes having multiple isoforms in any organism so far studied, and the phenomena of multiple gene copy of complement 
genes seems to be sequestered to the genes encoding proteins of the three activation pathways (CP, AP, LP).

To examine the expression profile of $\mathrm{GcC} 8 \alpha$, RT-PCR revealed that $\mathrm{GcC} 8 \alpha$ is synthesized by several tissues in the shark, with the highest expression in the liver. Other tissues that synthesized GcC8 $\alpha$ were kidney, brain, intestine, ovary, muscle, heart, pancreas, erythrocytes, and leukocytes. Interestingly, the expression in peripheral blood cells is higher in erythrocytes than in leukocytes, which indicates that nucleated erythrocytes of shark are transcriptionally active. Multiple organ/cell expression of C8 $\alpha$ is not seen in mammals, where $\mathrm{C} 8 \alpha$ is synthesized primarily in the liver; however, in other vertebrate species such as trout, $C 8 \alpha$ and $C 8 \beta$ are expressed in several tissues (Kazantzi et al., 2003; Papanastasiou and Zakardis, 2006). Taken together these observations suggest that poikilothermic vertebrates synthesize complement proteins more ubiquitously than mammals. As the complement system evolved, the tissue sites for complement synthesis may have been reduced through evolution; however, the liver (hepatopancreas in some species) remains likely the main site of complement protein synthesis in vertebrates.

Phylogenetic analysis of $\mathrm{GcC} 8 \alpha$ provides insight into the evolution of the MAC family of proteins. Two main theories attempt to explain the evolution of this significant gene family. Phylogenetic analyses by Mondragon-Palomino et al. (1999) using MAC amino acid sequences supports the view that $\mathrm{C} 6$ and $\mathrm{C} 7$ are earlier in origin and were followed by the emergence of C8 then C9. Mondragon-Palomino et al. (1999) do not present data as to the whether $\mathrm{C} 8 \alpha$ or $\beta$ is of earlier derivation, and suggest that the 
terminal complex proteins ( $\mathrm{C} 6$ through $\mathrm{C} 9$ ) originated from a single ancestral gene composed of complex modular structure. They suggest that a series of gene duplications and loss of structural modules resulted in complement proteins that make up the MAC protein family. In contrast, Podack et al. (1991) hypothesize that, due to the similarity of function, size, and sequence, C9 emerged first from a gene duplication event of an ancestral gene common to both perforin and the MAC family proteins. Podack et al. (1991) further speculate that following C9 emergence, C8, C7, and C6 successively emerged through later gene duplication events and developed increasing modular complexity and size. Kauffman et al.'s (1993) hypothesis is somewhat different, although it also supports the $\mathrm{C} 8 / \mathrm{C} 9$ faction as originators of MAC. After distance analyses of human MAC components and perforin $C 8 \alpha$ Kauffman et al. (1993) show that $C 8 \alpha$ and $\beta$ have a closer phylogenetic distance to perforin than to $\mathrm{C} 6, \mathrm{C} 7$, and $\mathrm{C} 9$, maintaining that MAC arose from a fundamental C8-like building block. The phylogenetic analysis performed in this study supports the hypothesis that C8 and C9 are derived from a common ancestor and represent an early duplication event that most likely predated C6 and C7. Although C6-like molecules have been described for amphioxus (Suzuki et al., 2000) and Ciona (Wakoh et al., 2004), their role as complement proteins remains unconfirmed. Molecular analysis of the C6-like gene described for amphioxus reveals a 5' C6 modular structure with a 3' end that is missing key modules characteristic of C6. This could also be interpreted to be an early C 8 -like molecule before loss of the extra T1 module at the 5' end. Furthermore, in Ciona the C6-like gene is expressed as a cell surface receptor and whether it has a complement function (Wakoh et al., 2004; Azumi et al., 2003) in either organism is unknown. This amphioxus C6 gene has not been shown to 
be expressed or functional and may be C6-like only in sequence. Amphioxus C6 is also comparable in size to $C 8$ ( $\alpha$ and $\beta$ chains) and $C 9$.

The phylogeny constructed during this investigation showed that $\mathrm{GcC} 8 \alpha$ forms a clade with $\mathrm{C} 8 \alpha$ sequences from other taxa and is sister taxa with frog $\mathrm{C} 8 \alpha$. The tree also shows that the $\mathrm{C} 8$ complex has diverged from a common ancestor with $\mathrm{C} 9$. Human, mouse, cow, cat and woodchuck perforin sequences were used as an out group. Confidence in the branch points was validated by 1000 bootstrap replications. The tree also shows that the $\mathrm{C} 8$ complex has diverged from a common ancestor with $\mathrm{C} 9$. According to our phylogenetic analysis $\mathrm{C} 8 \alpha$ and $\mathrm{C} 8 \beta$ arose from $\mathrm{C} 9$ followed by $\mathrm{C} 7$, then C6. Since the presence or absence of $\mathrm{C} 7$ and/or C6 homologues in shark remains to be resolved it is premature to conclude that shark MAC only consists of $\mathrm{C} 5 \mathrm{~b}, \mathrm{C} 8$, and $\mathrm{C} 9$. C6 and C7 are essential to teleost, amphibian, and mammalian taxa or MAC function. If it were to be determined that one or the other of these two proteins was in fact absent in shark, the data would support Podack et al.'s (1991) hypothesis since C5 (Graham et al., 2009), C8, and C9 homologues are, so far the only MAC proteins confirmed for the shark.

The Western blot using goat anti-human C9 as the primary detection antibody revealed reactive bands above $250 \mathrm{kDa}$ under reducing and non-reducing conditions. This is likely due to cross-reactivity between the anti-human C9 antibody and aggregates of proteins possibly poly-C 9 or SC5b-9. There was also a reactive band at $71 \mathrm{kDa}$ under both reducing and non-reducing conditions, which corresponds to the molecular weight of human C9. Anti-human C9 antibodies detected a band at $\sim 40 \mathrm{kDa}$ in reduced sample of human serum. Shark serum and supernatant 1 under reducing and NR show bands at 
$49 \mathrm{kDa}$ and the shark serum under NR conditions revealed a band at $68 \mathrm{kDa}$. This band may represent shark $\mathrm{C} 9$ and suggests that the shark $\mathrm{C} 9$ may be slightly smaller than the $71 \mathrm{kDa}$ human homologue.

A band at $151 \mathrm{kDa}$ in human serum was revealed in Western blots using antihuman $\mathrm{C} 8$ antibodies which represents the human trimeric $\mathrm{C} 8$ molecular complex. Two additional bands were also detected at 60 and $62 \mathrm{kDa}$ representing $\mathrm{C} 8 \alpha$ and $\beta$ chains. These bands were also present in reduced human serum, however the full oligomer was detected only in the non-reduced serum sample, suggesting that DTT reduced the oligomer completely to its $\alpha$ and $\beta$ counterparts. In the lanes with shark serum and shark spt I, both under-reducing and non-reducing conditions, a faint band was present at 64 $\mathrm{kDa}$, signifying either $\mathrm{GcC} 8 \alpha$, a C8 $\beta$-like component, or both. Under the NR conditions, a faint band could be seen at $\sim 185 \mathrm{kDa}$ in all lanes with shark protein. The anti-human C8 antibody did not detect C8y in the human or shark fluids, suggesting that the C8 antibody was specific for epitopes that are similar on $C 8 \alpha$ and $C 8 \beta$ but not $C 8 \gamma$. Whereas $\mathrm{C} 8 \alpha$ and $\beta$ are so similar a single antibody would likely detect both and does in this instance. It is not surprising that $\mathrm{C} 8 \gamma$ was undetected as it is a lipocalin and small such that if the shark has $\mathrm{C} 8$, it would not likely be detected by this test.

Only one band is visualized on the C7 Western blot in the lane with the NR human serum at $110 \mathrm{kDa}$ representing human $\mathrm{C}$. This was absent when human serum was reduced. Although C7 does not exist as a covalently bound multimer, it is cysteine rich and has many internal disulfide bonds which were probably reduced by the DTT. This would change the topography of the protein and the integrity of its epitope and 
would account for non-reactivity with anti-C7 antiserum made to native protein. The same antibody failed to detect protein in any of the shark samples. This could mean that C7 in shark (should it be present) is antigenically distinct from its mammalian counterpart, or that the molecule is absent in sharks.

In Western blot using antiserum to human C6 no protein bands were detected in any of the samples run including human serum, suggesting that the antibody concentration was too low to achieve a detectable reaction of the antibody with its target epitope. Another possibility is that the antibody was specific for an epitope of the folded C6 and that the human serum was sub-optimal in that the disulfide bonds had been reduced over time or through handling obscuring the epitope the antibody was specific for. The question of $\mathrm{C} 6$ homologue in the shark remains unresolved. 


\section{REFERENCES}

Altschul S, Gish W, Miller W, Myers EW, and Lipman DJ. Basic local alignment search tool. Journal of Molecular Biology. 1990; 215:403-410.

Atkinson JP and Frank MM. Complement-independent clearance of IgG-sensitized erythrocytes: inhibition by cortisone. Blood. 1974a;44:629-37.

Atkinson JP and Frank MM. Studies on the in vivo effects of antibody. Interaction of IgM antibody and complement in the immune clearance and destruction of erythrocytes in man. Journal of Clinical Investigation. 1974b;5:339-48.

Azumi K, Santis RD, Tomaso AD, Rigoutsos I, Yoshizaki F, Pinto MR, et al. Genomic analysis of immunity in a Urochordate and the emergence of the vertebrate immune system: "waiting for Godot". Immunogenetics. 2003;55:570-81.

Brannen CL and Sodetz JM. Incorporation of human complement C8 into the membrane attack complex is mediated by a binding site located within the C8b MACPF domain. Molecular Immunology. 2007;44:960-5.

Brickner A and Sodetz JM. Function of subunits within the eighth component of human complement: selective removal of the $\gamma$ chain reveals it has no direct role in cytolysis. Biochemistry 1984; 23: 832-837.

Brickner A and Sodetz JM. Functional domains of the $\alpha \square$ subunit of the eighth component of human complement: identification and characterization of a distinct binding site for the $\gamma \square$ chain. Biochemistry $1985 ; 24: 4603-7$.

Campbell, ID. Modular proteins at the cell surface. Biochemical Society Transactions. 2003; 31:1007-1 I14.

Chondrou M, Papanastasiou AD, Spyroulias GA, and Zakardis IK. Three isoforms of complement properdin factor $P$ in trout: cloning, expression, gene organization and constrained modeling. Developmental and Comparative Immunology. 2008; 32:1454-66.

Dishaw LJ, Smith SL, and Bigger CH. Characterization of a C3-like cDNA in a coral: phylogenetic implications. Immunogenetics. 2005; 57:535-48.

Frohman MA, Dush MK, and Martin GR. Rapid production of full-length cDNAs from rare transcripts: amplification using a single gene-specific oligonucleotide primer. Proceedings of the National Academy of Sciences. 1988; 85:8998-9002. 
Fujii T and Murakawa S. Immunity in lamprey. III. Occurrence of the complement-like activity. Developmental and Comparative Immunology. 1981; 5:251-9.

Gongora R, Figueroa F, and Klein J. Independent duplications of Bf and C3 complement genes in the zebrafish. Scandanavian Journal of Immunology. 1998; 48:651-8.

Gonzalez S, Setién F, Coto E, and López-Larrea C. Genetic structure and organization of the membrane attack complement components. European Journal of Immunogenetics. $1996 ; 23: 181-197$.

Götze O and Müller-Eberhard HJ. The C3-activator system: an alternate pathway of complement activation. Journal of Experimental Medicine. 1971; 90-108.

Graham M, Shin D, and Smith SL. Molecular and expression analysis of complement component $\mathrm{C} 5$ in the nurse shark (Ginglymostoma cirratum) and its predicted functional role. Fish \& Shellfish Immunology. 2009; 27: 40-49.

Gross PS, Al-Sharif WZ, Clow LA, and Smith LC. Echinoderm immunity and the evolution of the complement system. Developmental and Comparative Immunology. $1999 ; 23: 429-442$.

Hadders MA, Beringer DX, Gros P. Structure of C8alpha-MACPF reveals mechanism of membrane attack in complement immune defense. Science. 2007; 317:1552-4.

Hall TA. BioEdit: a user-friendly biological sequence alignment editor and analysis program for Windows 95/98/NT. Nucleic Acids Symposium Series. 1999. 41:95-98.

Haefliger JA, Peitsch MC, Jenne DE, and Tschopp J. Structural and functional characterization of complement C8 gamma, a member of the lipocalin protein family. Molecular Immunology. I99I;28:123-31.

Hofsteenge J, Blommers M, Hess D, Furmanek A, and Miroshnichenko O. The four terminal components of the complement system are C-mannosylated on multiple tryptophan residues. Journal of. Biological. Chemistry. 1999; 274: 32786-94.

Humphrey JH and Dourmashkin RR. The lesions in cell membranes caused by complement. Advances in Immunology. 1969;11:75-115.

Jensen JA, Festa E, Smith DS, and Cayer M. The complement system of the nurse shark: hemolytic and comparative characteristics. Science. 1981;214:566-569.

Jensen JA, Fuller L, and Iglesias E. The terminal components of the nurse shark C system. Journal of Immunology. 1973; 111:306-307.

Kato Y, Nakao M, Mutsuro J, Zarkadis IK, and Yano T. The complement component 
C5 of the common carp (Cyprinus carpio): cDNA cloning of two distinct isotypes that differ in a functional site. Immunogenetics. 2003;54:807-15.

Kauffman DL, Keller PJ, Bennick A, and Blum M. Alignment of amino acid and DNA sequences of human proline-rich proteins. Critical reviews in oral biology and medicine. $1993 ; 4: 287-92$.

Kaufmann T, Rittner C and Schneider PM. The human complement component C8B gene: structure and phylogenetic relationship. Human Genetics. 1993; 92:69-75.

Kalagiri T, Hirono I, and Aoki T. Molecular analysis of complement component of C8 $\beta$ and C9 cDNAs of Japanese founder, Paralicththys olivaceous. Immunogenetics, 1999; 50: $43-48$.

Kazantzi A, Sfyroera G, Holland MG-H, Lambris JD, and Zarkadis IK. Molecular cloning of the beta subunit of complement component eight of the rainbow trout. Developmental and Comparative Immunology. 2003; 27:167-174.

Kimberley FC, Sivasankar B, and Morgan BP. Alternative roles for CD59. Molecular Immunology. 2007; 44:73-81.

Kolb WP, Haxby JA, Arroyave CM, Müller-Eberhard HJ. Molecular analysis of the membrane attack mechanism of complement. Journal of Experimental Medicine. 1972; 135:549-66.

Kolb WP and Muller-Eberhard HJ. Neoantigens of the membrane attack complex of human complement. Proceedings of the National Academy of Sciences. 1975; 72:16879.

Kolb WP and Müller-Eberhard HJ. The membrane attack mechanism of complement: the three polypeptide chain structure of the eighth component (C8). Journal of Experimental Medicine 1976;143:1131-9.

Kolb WP and Müller-Eberhard HJ. Mode of action of human C9: adsorption of multiple C9 molecules to cell-bound C8. Journal of Immunology. 1974; 113:479-88.

Kuroda N, Wada H, Naruse K, Simada A, Shima A, Sasaki M, and Nonaka M. Molecular cloning and linkage analysis of the Japanese medaka fish complement $\mathrm{Bf} / \mathrm{C} 2$ gene. Immunogenetics 1996; 44:459-67.

Kyte $\mathrm{J}$ and Doolittle RF. A simple method for displaying the hydropathic character of a protein Journal of molecular biology. I982; 157:105-32.

Lambris J, Reid K, and Volanakis J. The evolution, structure, biology and pathophysiology of complement. Immunology Today. 1999;20:207-11. 
Legler DW and Evans EE. Comparative immunology: hemolytic complement in elasmobranchs. Proceedings of the Society for Experimental Biology and Medicine. 1967;124:30-4.

Liszewski MK, Farries TC, Lublin DM, Rooney IA, and Atkinson JP. Control of the complement system. Adv Immunol. 1996;61:201-83.

Marino R, Kimura Y, De Santis R, Lambris JD and Pinto MR, Complement in urochordates: cloning and characterization of two $\mathrm{C} 3$-like genes in the ascidian Ciona intestinalis. Immunogenetics. 2002; 53:1055-1064.

Marshall RD. The nature and metabolism of the carbohydrate-peptide linkages of glycoproteins. Biochemical Society Symposium. 1974;(40):17-26.

McLin VA, Hu CH, Shah R, and Jamrich M. Expression of complement components coincides with early patterning and organogenesis in Xenopus laevis. International Journal of Developemental Biology. 2008;52:1123-33.

Mikrou A and Zarkadis IK. Cloning of the sixth complement component and, spatial and temporal expression profile of MAC structural and regulatory genes in chicken. Developmental and Comparative Immunology. 2010;34:485-90.

Mondragon-Palomino M, Pinero D, Nicholson-Weller A, and Laclette JP. Phylogenetic Analysis of the Homologous Proteins of the Terminal Complement Complex Supports the Emergence of C6 and C7 Followed by $\mathrm{C} 8$ and C9. Journal of Molecular Evolution. 1999;49:282-9.

Morley BJ and Walport MJ. The Complement Facts Book. Academic Press, 2000. P. $123-130$.

Muller-Eberhard HJ. Molecular organization and function of the complement system. Annual Review of Biochemistry. 1988; 57:321-347.

Musingarimi P, Plumb ME and Sodetz JM. Interaction between the C8 $\alpha-\gamma$ and C8 $\beta$ Subunits of Human Complement C8: Role of the C8 $\beta$ N-Terminal Thrombospondin Type 1 Module and Membrane Attack Complex/Perforin Domain. Biochemistry. 2002; 41:11255-11260.

Nakajima E, Itoh T, Suzuki K, Kawakami K, Takeda K, Onishi A, and Komatsu M. Characterization, chromosomal localization, and genetic variation of the alpha subunit of porcine eighth component of complement. Animal Genetics.1998; 29:377-80 
Nakao M, Kato-Unoki Y, Nakahara M, Mutsuro J, and Somamoto T. Diversified components of the bony fish complement system: more genes for robuster innate defense? Advances in experimental medicine and biology. 2006; 586:121-38.

Nakao M, Fushitani Y, Fujiki K, Nonaka M, and Yano T. Two diverged complement factor B/C2-like cDNA sequences from a teleost, the common carp (Cyprinus carpio). Journal of Immunology. 1998; 161:4811-8

Nakao M, Matsumoto M, Nakazawa M, Fujiki K, and Yano T. Diversity of complement factor $\mathrm{B} / \mathrm{C} 2$ in the common carp (Cyprinus carpio): three isotypes of B/C2-A expressed in different tissues. Developmental and Comparative Immunology. 2002; 26:533-41.

$\mathrm{Ng}$ SC, Rao AG, Howard OM, and Sodetz JM. The eighth component of human complement (C8): evidence that it is an oligomeric serum protein assembled from products of three different genes. Biochemistry. 1987; 26:5229-5233.

Nonaka M. Evolution of the complement system. Current Opinion in Immunology. 2001;13:69-73.

Nonaka M, Fujii T, Kaidoh T, Natsuume-Sakai S, Nonaka M, Yamaguchi N, and Takahashi M. Purification of a lamprey complement protein homologous to the third component of the mammalian complement system. Journal of Immunology. 1984; 133:3242-9.

Nonaka $\mathrm{M}$ and Smith SL. Complement system of bony and cartilaginous fish. Fish and Immunology. 2000; 10:215-28.

Nonaka M, Takahashi M, and Sasaki M. Molecular Cloning of a Lamprey Homologue of the Mammalian MHC Class 111 Gene, Complement Factor B. The Journal Immunology. 1994; 152: $2263-2269$.

Nonaka M, Yamaguchi N, Natsuume-Sakai S, and Takahashi M. The complement system of rainbow trout (Salmo gairdneri). Identification of the serum lytic system homologous to mammalian complement. Journal of Immunology. 1981; 126:1489-94.

Nonaka M, Azumi K, Ji X, Namikawa-Yamada C, Sasaki M, Saiga H, Dodds AW, Sekine H, Homma MK, Matsushita M, Endo Y, Fujita T. Opsonic complement component $\mathrm{C} 3$ in the solitary ascidian, Halocynthia roretzi. Journal Immunology. $1999 ; 162: 387-91$.

Ohno, S. Evolution by gene duplication. Springer-Verlag, Berlin. 1970.

Papanastiou AD, Georgaka E, and Zakardis IK. Cloning of CD59-like gene in rainbow trout. Expression and phylogenetic analysis of two isoforms. Molecular Immunology. 2007;44:1300-6. 
Papanastasiou AD and Zakardis IK. Gene duplication of the seventh component of complement in rainbow trout. Immunogenetics. 2005; 57:703-8.

Papanastasiou AD and Zarkadis IK. Cloning and phylogenetic analysis of the alpha subunit of the eighth complement component (C8) in rainbow trout. Molecular Immunology. 2006a; 43:2188-94.

Papanastasiou AD and Zarkadis IK. The gamma subunit of the eighth complement component (C8) in rainbow trout. Developmental and Comparative Immunology. 2006b; 30:485-91.

Parker CL and Sodetz JM. Role of the human C8 subunits in complement-mediated bacterial killing: evidence that $\mathrm{C} 8 \gamma$ is not essential. Molecular Immunology. 2002;39:453-8.

Peitsch MC, Amiguet P, Guy R, Brunner J, Maizel JV, and Tschopp J. Localization and molecular modelling of the membrane-inserted domain of the ninth component of human complement and perforin. Molecular Immunology. 1990; 27:589-602.

Platteborze PL, Hobart MJ, and Sodetz JM. Physical linkage and orientation of the human complement $\mathrm{C} 8$ alpha and $\mathrm{C} 8$ beta genes on chromosome 1p32. Human Genetics. 1996; 98:443-6.

Plumb ME, Scibeck JJ, Barber TD, Dunlap RJ, Platteborze PL, and Sodetz JM. Chimeric and truncated forms of human complement protein $\mathrm{C} 8$ alpha reveal binding sites for $\mathrm{C} 8$ beta and C8 gamma within the membrane attack complex/perforin region. Biochemistry. $1999 ; 38: 8478-84$.

Plumb ME and Sodetz JM. An Indel within the C8 $\alpha$ Subunit of Human Complement C8 Mediates Intracellular Binding of $\mathrm{C} 8 \gamma$ and Formation of $\mathrm{C} 8 \alpha-\gamma \mathrm{Bag}$. Biochemistry. 2000; 39:13078-13083.

Podack ER. Assembly and structure of the membrane attack complex (MAC). In: Podack, editor. Cytolytic lymphocytes and complement: effectors of the immune system, vol. 1. Boca Raton: CRC Press. 1988; p. 173-84.

Podack ER, Biesecker G, Kolb WP, Müller-Eberhard HJ. The C5b-6 complex: reaction with C7, C8, C9. Journal of Immunology. 1978; 121:484-90.

Podack ER and Tschopp J. Membrane attack by complement. Molecular Immunology. 1984; 7:589-603.

Podack ER, Olsen KJ, Lowrey DM, and Lichtenheld M. Structure and function of perforin. Current Topics in Microbiology and Immunology. 1989;140:11-7. 
Podack ER, Hengartner H, Lichtenheld MG. A central role of perforin in cytolysis? Annual Review of Immunology. 1991; 9:129-47.

Ramm LE, Whitlow MB, and Mayer MM. Size of the transmembrane channels produced by complement proteins C5b-8. Journal of Immunology. 1982;129:1143-6.

Rittner C, Hargesheimer W, Stradmann B, Bertrams J, Baur MP, and Petersen BH. Human C81 (alpha-gamma) polymorphism: detection in the alpha-gamma subunit on SDS-PAGE, formal genetics and linkage relationship. American Journal of Human Genetetics. 1986; 38:482-91.

Saitou N and Nei M. The neighbor-joining method: a new method for reconstructing phylogenetic trees. Molecular Biology and Evolution. 1987; 4:406-25.

Sanger F, Nicklen S, and Coulson AR. DNA sequencing with chain-terminating inhibitors. Proceedings of the National Academy of Sciences. 1977; 74:5463-5467.

Scapigliati G, Buonocore F, Bird S, Zou J, Pelegrin P, Falasca C, Prugnoli D, Secombes CJ. Phylogeny of cytokines: molecular cloning and expression analysis of sea bass Dicentrarchus labrax interleukin-1beta. Fish Shellfish Immunology. 2001;11:711-26

Scibek JJ, Plumb ME, and Sodetz JM. Binding of Human Complement C8 to C9: Role of the N-Terminal Modules in the C8B Subunit. Biochemistry. 2002; 41:14546-51.

Shin DH, Webb B, Nakao M, and Smith, SL. Molecular cloning, structural analysis and expression of complement component $\mathrm{Bf} / \mathrm{C} 2$ genes in the nurse shark, Ginglymostoma cirratum. Developmental and Comparative Immunology. 2007; 31:1168-1182.

Shin DH, Webb BM, Nakao M, and Smith SL. Characterization of shark complement factor I gene(s): genomic analysis of a novel shark-specific sequence. Molecular Immunology. 2009; 46:2299-308.

Slade DJ, Chiswell B; and Sodetz JM. Functional studies of the MACPF domain of human complement protein $\mathrm{C} 8$ alpha reveal sites for simultaneous binding of $\mathrm{C} 8$ beta, $\mathrm{C} 8$ gamma, and C9. Biochemistry. 2006; 45:5290-6.

Smith LC, Azumi K, Nonaka M. Clow LA, and Terwilliger DP. The ancestral complement system in sea urchins. Immunological Reviews. 2001; 180:16-34.

Smith, LC, Azumi K, and Nonaka M. Complement systems in invertebrates. The ancient alternative and lectin pathways. Immunopharmacology 1999; 42:107-120.

Smith, SH and Jensen JA. The second component (C2n) of the nurse shark complement system: purification, physico-chemical characterization and functional comparison with guinea pig C4. Developmental and Comparative Immunolology. 1986; 10:191-206. 
Smith, SL. Shark complement: an assessment. Immunological Reviews 1998; 166:6778.

Sodetz JM. Structure and Function of C8 in the membrane attack sequence of complement. Current Topics in Microbiology and Immunology. 1989; 140:19-31.

Sodetz JM and Plumb ME. Complement: Terminal Pathway. Encyclopedia of life sciences. 2001; Nature Publishing Group: www.els.net.

Steckel EW, Welbaum BE, and Sodetz JM. Evidence of direct insertion of terminal complement proteins into cell membrane bilayers during cytolysis: labeling by a photosensitive membrane probe reveals a major role for the eighth and ninth components. Journal of Biological Chemistry. 1983; 258:4318-4324.

Steckel EW, York RG, Monahan JB, and Sodetz JM. The eighth component of human complement: purification and physico-chemical characterization of its unusual subunit structure. Journal of Biological Chemistry. 1980; 255:11997-12005.

Sunyer JO, Tort L, and Lambris JD. Structural C3 diversity in fish: characterization of five forms of C3 in the diploid fish Sparus aurata. Journal of Immunolology. 1997; 158:2813-21.

Sunyer JO, Zarkadis IK, and Lambris, JD. Complement diversity: a mechanism for generating immune diversity? Immunology Today. 1998; 19:519-523.

Sunyer JO, Zarkadis IK, Sahu A, and Lambris JD. Multiple forms of complement C3 in trout that differ in binding to complement activators. Proceedings of the National Academy of Sciences. 1996; 93:8546-51.

Suzuki NM, Satoh N, and Nonaka M. C6-like and C3-like molecules from the cephalochordate, amphioxus, suggest a cytolytic complementsystem in invertebrates. Journal of Molecular Evolution. 2002; 54:671-679.

Swofford, DL. PAUP*. Phylogenetic Analysis Using Parsimony (*and Other Methods). Version 4. 2002. Sinauer Associates, Sunderland, Massachusetts.

Terado T, Nonaka MI, Nonaka M, and Kimura H. Conservation of the modular structure of complement factor I through vertebrate evolution. Journal of Developmental and Comparative Immunology. 2002; 26:403-13.

Terado T, Smith SL, Nakanishi T, Nonaka MI, Kimura H, Nonaka M.Occurrence of structural specialization of the serine protease domain of complement factor $\mathrm{B}$ at the emergence of jawed vertebrates and adaptive immunity. Immunogenetics. 2001;53:250-4. 
Trojer P, Wojnar P, Merschak P, and Redl B. Complement component C8 $\gamma$ is expressed in human fetal and adult kidney independent of C8a. FEBS Letters. 1999; 446:243-6.

Thompson JD, Gibson TJ, Plewniak F, Jeanmougin F, and Higgins DG. The CLUSTAL_X windows interface: flexible strategies for multiple sequence alignment aided by quality analysis tools. Nucleic Acids Research 1997; 25:4876-82.

Thomson JD, Higgins DG, and Gibson TJ. ClustalW: improving the sensitivity of progressive multiple sequence alignment through sequence weighting, position-specific gap penalties and weight matrix choice. Nucleic Acids Research. 1994; 22:4673-80.

Uemura T, Yano T, Shiraishi H, and Nakao M. Purification and characterization of the eighth and ninth components of carp complement. Molecular Immunology. 1996; 33: $925-32$

Volanakis J and Frank MM. Overview of the complement system. In: Volanakis, editor. The human complement system in health and disease. New York: Marcel Dekker. 1998; p. 9-31.

Wakoh T, Ikeda M, Uchino R, Azumi K, Nonaka M, Kohara Y, et al. Identification of transcripts expressed preferentially in hemocytes of Ciona intestinalis that can be used as molecular markers. DNA Research. 2004;11:345-52.

Wells L, Vosseller K, and Hart GW. Glycosylation Nucleocytoplasmic Proteins: Signal Transduction and O-GlcNAc. Science. 2001; 291:2376-8.

Young JD, Cohn ZA, Podack ER. The ninth component of complement and the poreforming protein (perforin 1) from cytotoxic T cells: structural, immunological, and functional similarities. Science. 1986; 233:184-90.

Young JD, Liu CC, Leong LG, and Cohn ZA. The pore-forming protein (perforin) of cytolytic $\mathrm{T}$ lymphocytes is immunologically related to the components of membrane attack complex of complement through cysteine-rich domains. Journal of Experimental Medicine.1986;164:2077-82. 